\title{
Retinal Optical Coherence Tomography in Neuromyelitis Optica
}

Frederike Cosima Oertel, MD/PhD, Svenja Specovius, MSc, Hanna G. Zimmermann, PhD, Claudia Chien, PhD, Seyedamirhosein Motamedi, PhD, Charlotte Bereuter, BSc, Lawrence Cook, PhD,

Marco Aurélio Lana Peixoto, MD, PhD, Mariana Andrade Fontanelle, MD, Ho Jin Kim, MD, PhD, Jae-Won Hyun, MD, PhD, Jacqueline Palace, MD, Adriana Roca-Fernandez, MSc, Maria Isabel Leite, MD, PhD, Srilakshmi Sharma, MD, PhD, Fereshteh Ashtari, MD, Rahele Kafieh, PhD, Alireza Dehghani, PhD, Mohsen Pourazizi, PhD, Lekha Pandit, MD, PhD, Anitha D'Cunha, PhD, Orhan Aktas, MD,

Marius Ringelstein, MD, Philipp Albrecht, MD, Eugene May, MD, Caryl Tongco, Letizia Leocani, MD, PhD, Marco Pisa, MD, Marta Radaelli, MD, PhD, Elena H. Martinez-Lapiscina, MD, PhD, Hadas Stiebel-Kalish, MD, Sasitorn Siritho, MD, Jérome de Seze, MD, PhD, Thomas Senger, MD, Joachim Havla, MD,

Romain Marignier, MD, PhD, Alvaro Cobo Calvo, MD, PhD, Denis Bichuetti, MD, PhD,

Ivan Maynart Tavares, MD, PhD, Nasrin Asgari, MD, PhD, Kerstin Soelberg, MD, Ayse Altintas, MD,

Rengin Yildirim, MD, Uygur Tanriverdi, MD, Anu Jacob, MD, Saif Huda, MD, PhD, Zoe Rimler, BSc, Allyson Reid, MD, Yang Mao-Draayer, MD, PhD, Ibis Soto de Castillo, MD, Axel Petzold, MD, PhD, Ari J. Green, MD, Michael R. Yeaman, MD, PhD, Terry Smith, MD, Alexander U. Brandt, MD, * and Friedemann Paul, MD*

Neurol Neuroimmunol Neuroinflamm 2021;8:e1068. doi:10.1212/NXI.0000000000001068
Correspondence

Dr. Paul

friedemann.paul@charite.de

\section{Abstract}

\section{Background and Objectives}

To determine optic nerve and retinal damage in aquaporin-4 antibody (AQP4-IgG)-seropositive neuromyelitis optica spectrum disorders (NMOSD) in a large international cohort after previous studies have been limited by small and heterogeneous cohorts.

\section{Methods}

The cross-sectional Collaborative Retrospective Study on retinal optical coherence tomography (OCT) in neuromyelitis optica collected retrospective data from 22 centers. Of 653 screened participants, we included $283 \mathrm{AQP} 4-\mathrm{IgG}-$ seropositive patients with NMOSD and 72 healthy controls (HCs). Participants underwent OCT with central reading including quality

\begin{abstract}
*These authors contributed equally to this work.
From the Experimental and Clinical Research Center (F.C.O., Svenja Specovius, H.G.Z., C.C., S.M., C.B., A.U.B., F.P.), Max Delbrück Center for Molecular Medicine and CharitéUniversitätsmedizin Berlin, Corporate Member of Freie Universität Berlin and Humboldt-Universität zu Berlin, Germany: NeuroCure Clinical Research Center (F.C.O., Svenja Specovius, H.G.Z., C.C., S.M., C.B., A.U.B., F.P.), Charité-Universitätsmedizin Berlin, Corporate Member of Freie Universität Berlin, Humboldt-Universität zu Berlin, Germany; Department of Neurology (F.C.O., A.J.G.), University of California San Francisco, CA; Department of Pediatrics (L.C.), University of Utah, Salt Lake City; CIEM MS Research Center (M.A.L.P., M.A.F.), University of Minas Gerais, Medical School, Belo Horizonte, Brazil; Department of Neurology (H.J.K., J.-W.H.), National Cancer Center, Goyang, Republic of Korea; Department of Neurology (J.P., A.R.-F., M.I.L.), and Department of Ophthalmology (Srilakshmi Sharma), and Department of Ophthalmology (Srilakshmi Sharma), Oxford University Hospitals, National Health Service Trust, UK; Kashani MS Center (F.A.), School of Advanced Technologies in Medicine and Medical Image and Signal Processing Research Center (R.K.), Department of Ophthalmology, Isfahan Eye Research Center (A.D., Mohsen Pourazizi), Isfahan University of Medical Sciences, Iran; Department of Neurology (L.P., A.D'C.), KS Hegde Medical Academy, Nitte University, Mangalore, India; Department of Neurology (O.A., Marius Ringelstein, P.A.), Medical Faculty, Heinrich Heine University Düsseldorf, Germany; Swedish Neuroscience Institute Neuro-Ophthalmology (E.M., C.T.), Seattle, WA; Experimental Neurophysiology Unit (L.L., Marco Pisa, Marta Radaelli), Institute of Experimental Neurology (INSPE) Scientific Institute Hospital San Raffaele and University Vita-Salute San Raffaele, Milan, Italy; Hospital Clinic of Barcelona-Institut d'Investigacions (E.H.M.-L.), Biomèdiques August Pi Sunyer, (IDIBAPS), Spain; Sackler School of Medicine (H.S.-K.), Tel Aviv University, Israel; Neuro-Ophthalmology Division (H.S.-K.), Department of Ophthalmology, Rabin Medical Center, Petah Tikva, Israel; Division of Neurology (Sasitorn Siritho), Department of Medicine, Siriraj Hospital and Bumrungrad International Hospital, Bangkok, Thailand; Neurology Service (.d.S., Thomas Senger), University Hospital of Strasbourg, France; Institute of Clinical Neuroimmunology (J.H.), Biomedical Center and University Hospital, Ludwig-Maximilians Universitaet Muenchen, Munich, Germany; Neurology (R.M., A.C.C.), Multiple Sclerosis, Myelin Disorders and Neuroinflammation, Pierre Wertheimer Neurological Hospital, Hospices Civils de Lyon, France; Centre d'Esclerosi Múltiple de Catalunya (Cemcat) (A.C.C.), Department of Neurology/Neuroimmunology, Hospital Universitari Vall d'Hebron, Universitat Autònoma de Barcelona, Spain; Department of Neurology and Neurosurgery (D.B., I.M.T.), Escola Paulista de Medicina, Universidade Federal de São Paulo, Brazil; Departments of Neurology (N.A.), Slagelse Hospitals, Institute of Regional Health Research, University of Southern Denmark, Odense; Institute of Regional Health Research (N.A., K.S.), University of Southern Denmark, Odense; Department of Neurology (A.A., U.T.), and Department of Ophthalmology (R.Y.), Cerrahpasa Medical Faculty, Istanbul University, Turkey; The Walton Centre for Neurology and Neurosurgery (A.J., S.H.), Liverpool, UK; The Cleveland Clinic Abu Dhabi (A.J.), United Arab Emirates; NYU Multiple Sclerosis Comprehensive Care Center (Z.R., A.R.), Department of Neurology, NYU School of Medicine, New York; Department of Neurology (Y.M.-D.), University of Michigan Medical School, Ann Arbor; Department of Neurology (I.S.C.), Hospital Clínico de Maracaibo, Venezuela; Moorfield's Eye Hospital (A.P.), University College London, UK; Department of Medicine (M.R.Y.), Los Angeles Biomedical Research Institute at HarborUniversity of California at Los Angeles (UCLA) Medical Center, Torrance, CA, United States of America; Department of Medicine (M.R.Y.), David Geffen School of Medicine at UCLA, Los Angeles, CA, United States of America; Departments of Ophthalmology and Visual Sciences (Terry Smith), Kellogg Eye Center, University of Michigan Medical School, Ann Arbor, United States of America; Division of Metabolism (Terry Smith), Endocrine and Diabetes, Department of Internal Medicine, University of Michigan Medical School, Ann Arbor; Department of Neurology (A.U.B.), University of California, Irvine; and Department of Neurology (F.P.), Charité-Universitätsmedizin Berlin, Corporate Member of Freie Universität Berlin and Humboldt-Universität zu Berlin, Germany.
\end{abstract}

Go to Neurology.org/NN for full disclosures. Funding information is provided at the end of the article.

The Article Processing Charge was funded by the authors.

This is an open access article distributed under the terms of the Creative Commons Attribution-NonCommercial-NoDerivatives License 4.0 (CC BY-NC-ND), which permits downloading and sharing the work provided it is properly cited. The work cannot be changed in any way or used commercially without permission from the journal. 


\section{Glossary}

AQP4-IgG = aquaporin-4 IgG; CROCTINO = Collaborative Retrospective Study on retinal OCT in Neuromyelitis Optica; EDSS = Expanded Disability Status Scale; GCIP = ganglion cell and inner plexiform; HC = healthy control; HC-VA = highcontrast visual acuity; INL = inner nuclear layer; $\mathbf{M M E}=$ microcystic macular edema; $\mathbf{M S}=$ multiple sclerosis; $\mathbf{M O G}$-IgG = myelin oligodendrocyte glycoprotein IgG; NMOSD = neuromyelitis optica spectrum disorder; NMOSD-NON = NMOSD eyes without a history of ON; OCT = optical coherence tomography; $\mathbf{O N}=$ optic neuritis; $\mathbf{p R N F L}=$ peripapillary retinal nerve fiber layer; $\mathbf{S E}$ = standard error; VA = visual acuity; VEP = visually evoked potential.

control and intraretinal segmentation. The primary outcome was thickness of combined ganglion cell and inner plexiform (GCIP) layer; secondary outcomes were thickness of peripapillary retinal nerve fiber layer (pRNFL) and visual acuity (VA).

\section{Results}

Eyes with ON (NMOSD-ON, $\mathrm{N}=260)$ or without ON (NMOSD-NON, $\mathrm{N}=241)$ were assessed compared with $\mathrm{HCs}(\mathrm{N}=$ 136). In NMOSD-ON, GCIP layer $(57.4 \pm 12.2 \mu \mathrm{m})$ was reduced compared with HC (GCIP layer: $81.4 \pm 5.7 \mu \mathrm{m}, p<0.001$ ). GCIP layer loss $(-22.7 \mu \mathrm{m})$ after the first $\mathrm{ON}$ was higher than after the next $(-3.5 \mu \mathrm{m})$ and subsequent episodes. pRNFL observations were similar. NMOSD-NON exhibited reduced GCIP layer but not pRNFL compared with HC. VA was greatly reduced in NMOSD-ON compared with HC eyes, but did not differ between NMOSD-NON and HC.

\section{Discussion}

Our results emphasize that attack prevention is key to avoid severe neuroaxonal damage and vision loss caused by ON in NMOSD. Therapies ameliorating attack-related damage, especially during a first attack, are an unmet clinical need. Mild signs of neuroaxonal changes without apparent vision loss in $\mathrm{ON}$-unaffected eyes might be solely due to contralateral $\mathrm{ON}$ attacks and do not suggest clinically relevant progression but need further investigation.

Patients with neuromyelitis optica spectrum disorder (NMOSD) experience recurrent optic neuritis $(\mathrm{ON}),{ }^{1}$ resulting in vision loss and decreased quality of life. ${ }^{1-4}$ According to our understanding, there are at least 3 subtypes based on serostatus: $U p$ to 3 of 4 patients manifest as anti-aquaporin-4 IgG (AQP4-IgG) seropositive. Approximately half of the AQP4-IgG-seronegative patients manifest as anti-myelin oligodendrocyte glycoprotein IgG (MOG-IgG) seropositive, and half are double seronegative. ${ }^{5}$ Yet, clinical correlates of serologic phenotypes, including subclinical or clinical retinal degeneration and vision loss, remain unclear. ${ }^{6,7}$

Optical coherence tomography (OCT) is an interferometric technique producing high-resolution retinal images. ${ }^{1,8}$ OCT has become a reliable tool for diagnosing and monitoring neurologic and neuro-ophthalmologic diseases, especially for quantifying neurodegeneration after ON. ${ }^{1}$ Because of limited samples and varying methods, existing OCT studies in NMOSD are inconsistent regarding the amount of retinal neurodegeneration with and without ON. Previous studies also failed to address the influence of retinal neurodegeneration on microcystic macular edema (MME) and function. ${ }^{2,6,7}$ These issues together with heterogeneities and the often monocentric character of previous cohorts limit the relevance of metaanalyses.

To overcome these limitations, we performed an OCT analysis of AQP4-IgG-seropositive patients with NMOSD in an international multicenter study, termed Collaborative Retrospective Study on retinal OCT in Neuromyelitis Optica (CROCTINO). ${ }^{9}$
It represents the largest NMOSD OCT data set and additionally validated an OCT postprocessing approach to circumvent differences in acquisition and imaging processing protocols inherent to pooled analyses. ${ }^{10}$ Outcomes include: (1) distinguishing retinal neurodegeneration after $\mathrm{ON}$ from subtle damage in clinically unaffected eyes, (2) defining frequency of $\mathrm{MME}$, and (3) deriving structure-function correlations.

\section{Methods}

\section{Study Design}

This cross-sectional international multicenter study was performed under the aegis of the CROCTINO study, which was a collaborative effort within the Guthy-Jackson Charitable Foundation network. ${ }^{9}$ Participating centers contributed OCT data (acquired between 2008 and 2018) and clinical metadata (acquired between 2000 and 2018, eTable 1, links.lww.com/ NXI/A557).

\section{Cohort Selection}

Inclusion criteria for this analysis were (1) patients diagnosed with NMOSD per the 2015 International Panel of NMOSD diagnosis criteria ${ }^{11}$ and (2) having confirmed serum AQP4IgG. Exclusion criteria were (1) comorbidities potentially confounding interpretation of OCT results (e.g., macular degeneration, glaucoma, and intracranial hypertension); (2) > 3 months distance between clinical and OCT data acquisition; (3) < 6 months between OCT imaging and most recent ON, or (4) an uncertain history of ON. The inclusion and 
Table 1 Cohort Description for AQP4-IgG-Seropositive Patients With NMOSD and HCS

\begin{tabular}{lll}
\hline & $\begin{array}{l}\text { AQP4- } \\
\text { IgG-seropositive } \\
\text { NMOSD }\end{array}$ & HC \\
\hline Subjects (N) & 283 & 72 \\
\hline Eyes (N) & 501 & 136 \\
\hline Sex (male/female, N/N [\%/\%]) & $28 / 255(9.9 / 90.1)$ & $\begin{array}{l}26 / 46(36.1 / \\
63.9)\end{array}$ \\
\hline Age (y, mean \pm SD) & $44.1 \pm 14.2$ & $30.9 \pm 7.7$ \\
\hline Ethnicity (N [\%]) & & \\
\hline Asian & $77(27.2)$ & $16(22.2)$ \\
\hline Black/African American & $13(4.6)$ & $0(0)$ \\
\hline White, Hispanic/Latino & $4(1.4)$ & $1(1.4)$ \\
\hline White, Non-Hispanic & $159(56.2)$ & $55(76.4)$ \\
\hline Other/nonreported & $30(10.6)$ & $0(0)$ \\
\hline
\end{tabular}

Disease-modifying therapy $(\mathrm{N}$

[\%])

\begin{tabular}{ll}
\hline Rituximab & $73(25.8)$ \\
\hline Azathioprine & $67(23.7)$ \\
\hline Oral prednisolone & $53(18.7)$ \\
\hline Mycophenolate mofetil & $48(17.0)$ \\
\hline Methotrexate & $8(2.8)$ \\
\hline Time since onset $(y$, mean \pm SD) & $7.2 \pm 6.7$ \\
\hline EDSS score (median [IQR]) & $3.5(2.0-4.5)$ \\
\hline
\end{tabular}

Patients with a clinical history of 204 (72.1)

ON (N [\%])

Eyes with a clinical history of ON $260(52)$

(N [\%])

No. of ON episodes/eye (N,
median [min-max])

Time since last ON (mo, mean $\pm \quad 71 \pm 57$

SD)

Abbreviations: AQP4-IgG = aquaporin-4 antibodies; NMOSD = neuromyelitis optica spectrum disorder; $\mathrm{HC}=$ healthy control; $\mathrm{N}=$ number; $\mathrm{OCT}=$ optical coherence tomography; $\mathrm{ON}=$ optic neuritis episode.

Age $(p<0.0001)$ and sex $(p<0.0001)$ were not matched

exclusion criteria are depicted in eFigure 1, links.lww.com/ NXI/A556. AQP4-IgG testing was performed at the discretion of each investigator.

\section{Standard Protocol Approvals, Registrations, and Patient Consents}

All participants gave written informed consent, and the study was approved by local ethics committees and conducted in accordance with the applicable laws and the current version of the Declaration of Helsinki. Data are reported according to STROBE reporting guidelines. ${ }^{12}$
OCT

High-resolution imaging data were acquired using 3 different spectral domain OCT devices: Spectralis SD-OCT (Heidelberg Engineering, Heidelberg, Germany) at 15 centers (194 patients/358 eyes; 72 healthy controls [HCs]/136 eyes); Cirrus HD-OCT (Carl Zeiss Meditec, Dublin, CA) at 6 centers (58 patients/87 eyes); or Topcon 3D OCT-1 (Topcon, Tokyo, Japan) at 1 center (31 patients/56 eyes). All reading of OCT data was performed at CharitéUniversitätsmedizin Berlin Translational Neuroimaging Group by 5 graders. Image quality was assessed using modified OSCAR-IB criteria by one of the graders, respectively. ${ }^{13,14}$ OCT segmentation for the combined ganglion cell and inner plexiform (GCIP) layer and inner nuclear layer (INL) thicknesses was corrected semi-automatically using an in-house software. $^{10,15}$ In brief, GCIP layer and INL thicknesses were calculated from a 5-mm diameter cylinder around the fovea excluding the central 1-mm diameter cylinder from a macular volume scan. ${ }^{10}$ The peripapillary retinal nerve fiber layer (pRNFL) thickness was measured and corrected according to the device protocol (Spectralis: peripapillary ring scan with $12^{\circ}$ or approximately $3.4 \mathrm{~mm}$ diameter around the optic disc; Topcon and Cirrus: extraction from optic disc volume scan). For the current analysis, eyes were excluded from the analysis if neither ring nor macular scan passed quality control. We further excluded data from the less common instrument for 1 center. The final cohort included 364 macular and 481 peripapillary scans of 501 eyes from 283 patients and 136 eyes from 72 HCs. Lower numbers of macular scans compared with peripapillary scans were due to both lower submission of macular data and more exclusions based on quality concerns.

\section{Visual and Global Function Testing}

High-contrast visual acuity (HC-VA) was available for 497 (99.2\%) patient and 10 (13.9\%) HC eyes. HC-VA was best corrected for $212(42.3 \%)$ patient and $56(41.2 \%) \mathrm{HC}$ eyes, habitually corrected for $145(28.9 \%)$ patient and $2(<0.1 \%)$ $\mathrm{HC}$ eyes, and without correction for 140 (27.9\%) patient eyes and $17(1.3 \%) \mathrm{HC}$ eyes. All VA data are reported as logMAR. VA measurement method was decided on discretion of each center. Visually evoked potentials (VEPs) were available for 167 (33.3\%) patient eyes and 40 (29.4\%) HC eyes, with P100 latency recorded as a binary value (normal/prolonged). Expanded Disability Status Scale (EDSS) scores were determined at the discretion of each center with data available for $180(63.6 \%)$ patients.

\section{Statistical Analysis}

Statistical analyses were performed with $\mathrm{R}$ version 3.6.1 using RStudio and R Markdown (RStudio Inc., Boston, MA) ${ }^{16} p$ Values less than 0.05 were considered significant. We considered $p$ values less than 0.10 a trend. Group matching by age and sex for confirmatory analyses was performed using automatic matching by R package MatchIt (method: exact). Group comparisons and correlations of $\mathrm{OCT}$ and VA values were performed using linear mixed- 

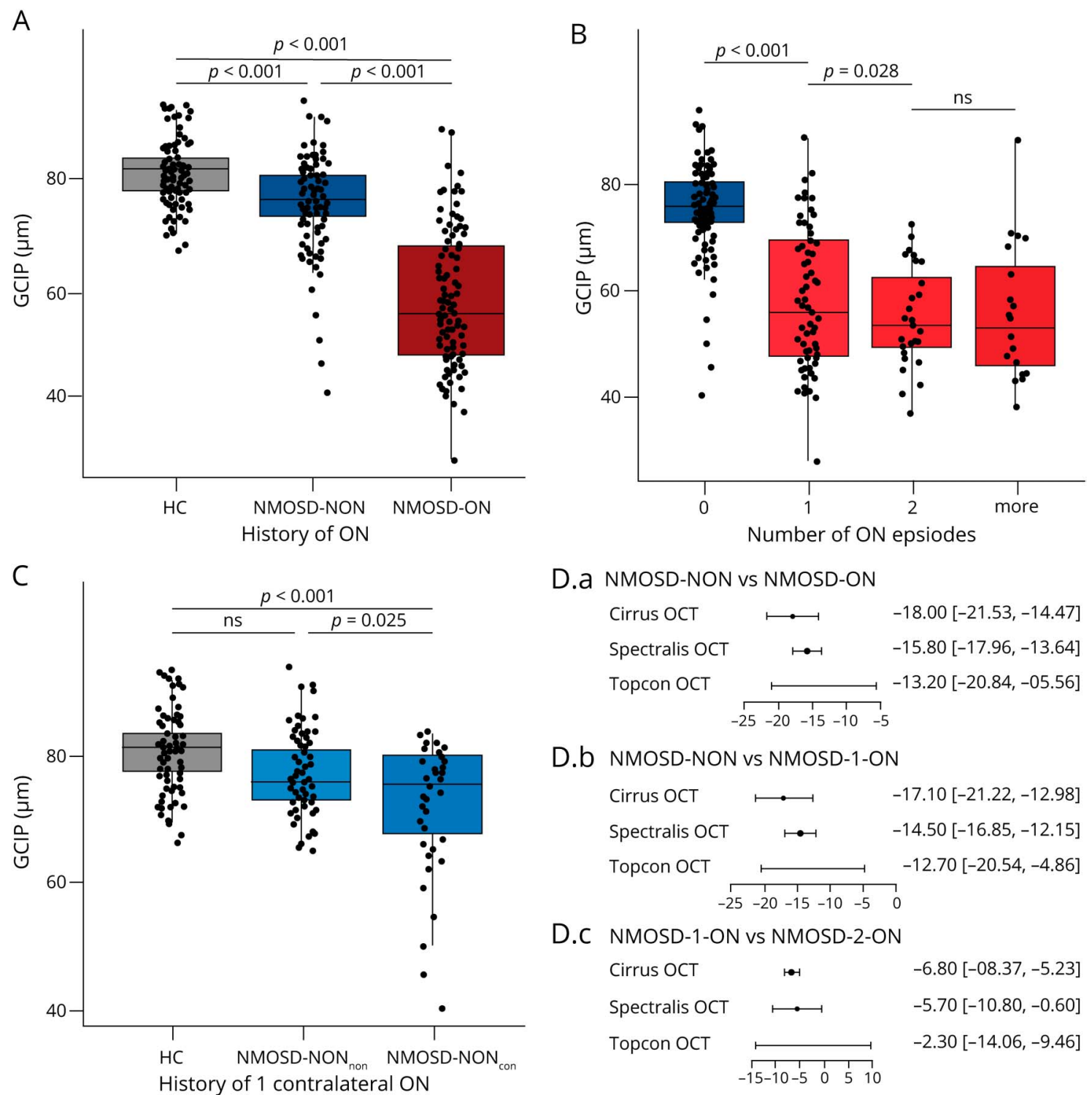

D.b NMOSD-NON vs NMOSD-1-ON

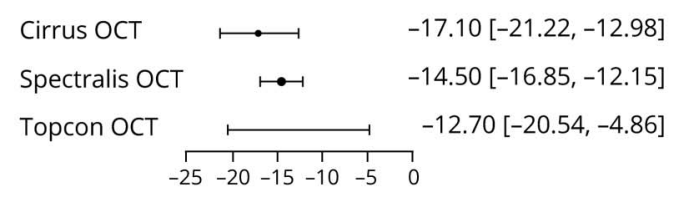

D.C NMOSD-1-ON vs NMOSD-2-ON

\begin{tabular}{|c|c|c|}
\hline Cirrus OCT & เө1 & $-6.80[-08.37,-5.23]$ \\
\hline Spectralis OCT & $\longmapsto$ & $-5.70[-10.80,-0.60]$ \\
\hline Topcon OCT & $\longrightarrow$ & $-2.30[-14.06,-9.46]$ \\
\hline
\end{tabular}

Boxplots of GCIP layer thicknesses $(\mu \mathrm{m})$ acquired by Heidelberg SD-OCT with values of individual eyes (jitter) for (A) HC (gray/left), NMOSD-NON (dark blue/middle), NMOSD-ON (dark red/right); for (B) number of ON episodes (NMOSD-NON dark blue/left, NMOSD-1-ON light red/left-middle,

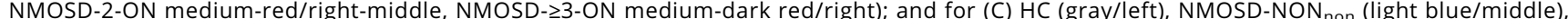

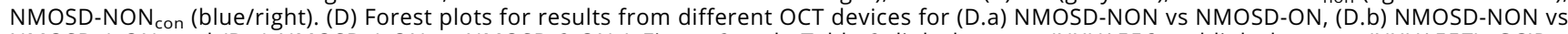
NMOSD-1-ON, and (D.C) NMOSD-1-ON vs NMOSD-2-ON (eFigure 2 and eTable 2, links.Iww.com/NXI/A556 and links.Iww.com/NXI/A557). GCIP = ganglion cell and inner plexiform; HC = eyes of HCs; NMOSD-NON = eyes of patients with neuromyelitis optica without a history of ON; NMOSD-NON-con = eyes of patients with neuromyelitis optica without a history of ON but a history of contralateral ON; NMOSD-NON non: $=$ eyes of patients with neuromyelitis optica without a history of ipsilateral or contralateral ON; NMOSD-ON = eyes of patients with neuromyelitis optica with a history of ON; NMOSD-1-ON = eyes of patients with neuromyelitis optica with a history of $1 \mathrm{ON}$ episode; NMOSD-2-ON = eyes of patients with neuromyelitis optica with a history of 2 ON episodes; $\mathrm{ON}=$ optic neuritis.

effect models. Intereye within-subject effects and effects of the center were included as random effects. Sex, ethnicity, and age were included as fixed effects for the analyses in the entire cohort. Age and sex were not included for the matched subset. For OCT parameters, the model was used for data from all devices separately and combined by Fisher combined probability test. The marginal and conditional coefficients of determination of the linear models were calculated with pseudo R-squared. All results are reported combined and individually for Spectralis SD-OCT; the analyses of data acquired by Cirrus HD-OCT or Topcon $3 \mathrm{D}$ OCT- 1 and for the matched subset are reported as online-only supplement.

\section{Data Availability}

The data supporting the findings of this study are available within the article and from the corresponding author by reasonable request. 

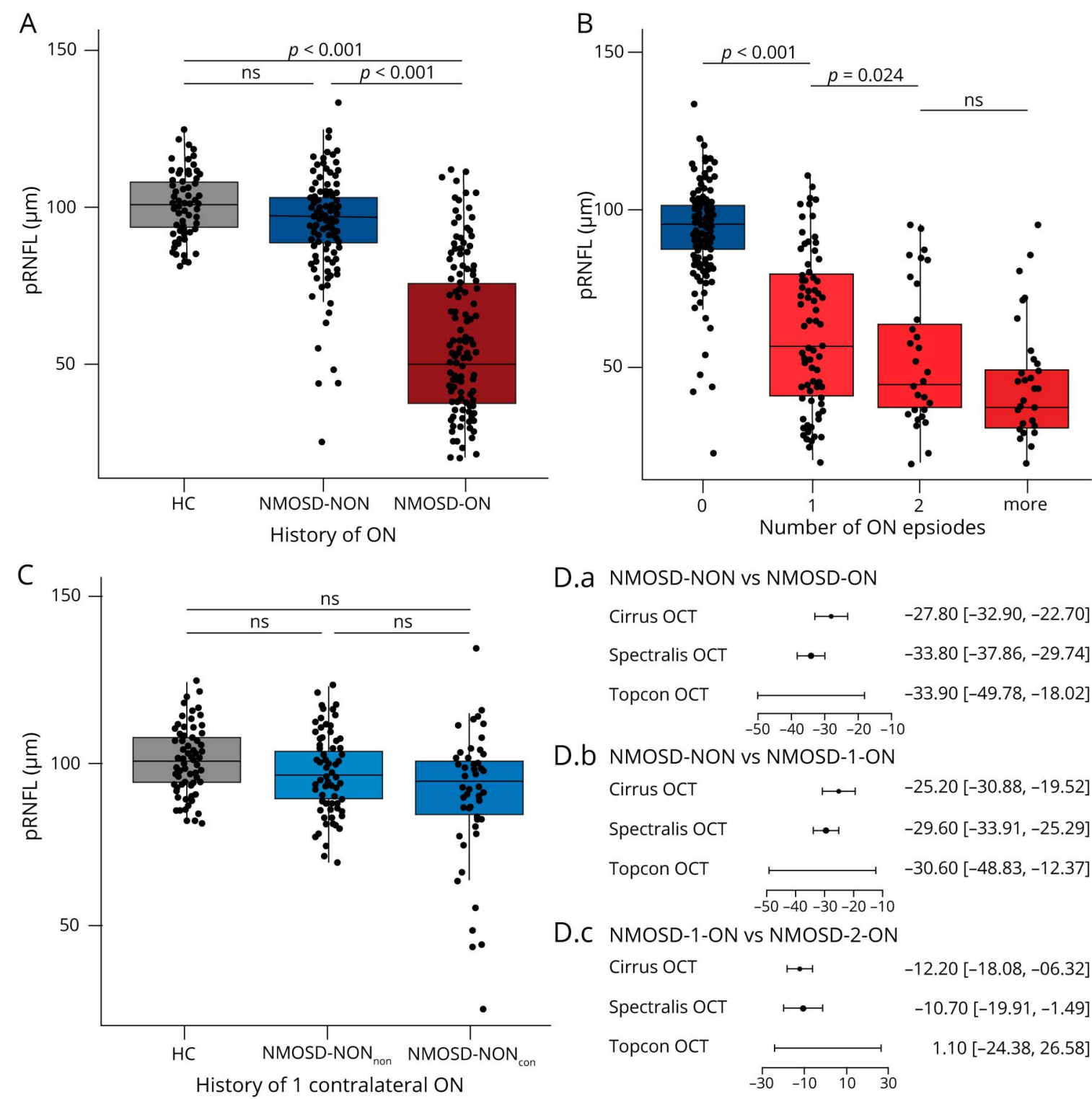

D.a NMOSD-NON vs NMOSD-ON

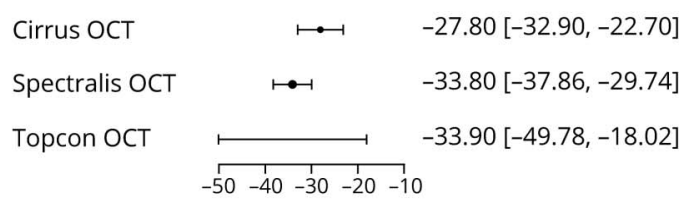

D.b NMOSD-NON vs NMOSD-1-ON

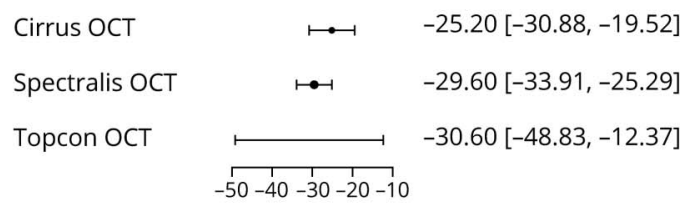

D.C NMOSD-1-ON vs NMOSD-2-ON

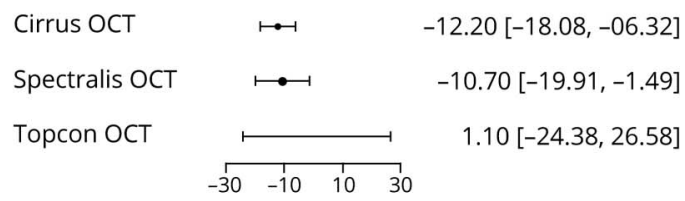

Boxplots of pRNFL thicknesses acquired by Heidelberg SD-OCT $[\mu \mathrm{m}]$ with values of individual eyes (jitter) for (A) HC (gray/left), NMOSD-NON (dark blue/ middle), and NMOSD-ON (dark red/right); for (B) number of ON episodes (NMOSD-NON dark blue/left, NMOSD-1-ON light red/left-middle, NMOSD-2-ON

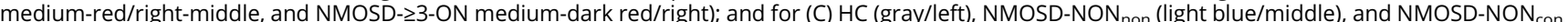
(blue/right). (D) Forest plots for results from different OCT devices for (D.a) NMOSD-NON vs NMOSD-ON, (D.b) NMOSD-NON vs NMOSD-1-ON, and (D.c) NMOSD-1-ON vs NMOSD-2-ON (eFigure 3 and eTable 3, links.Iww.com/NXI/A556 and links.lww.com/NXI/A557). HC = eyes of HCs; NMOSD-NON = eyes of patients with neuromyelitis optica without a history of optic neuritis; NMOSD-NON-con = eyes of patients with neuromyelitis optica without a history of optic neuritis but a history of contralateral optic neuritis; NMOSD-NON non: $^{2}$ eyes of patients with neuromyelitis optica without a history of ipsilateral or contralateral optic neuritis; NMOSD-ON = eyes of patients with neuromyelitis optica with a history of optic neuritis; NMOSD-1-ON = eyes of patients with neuromyelitis optica with a history of 1 optic neuritis episode; NMOSD-2-ON = eyes of patients with neuromyelitis optica with a history of 2 optic neuritis episodes; ON = optic neuritis; pRNFL = peripapillary retinal nerve fiber layer.

\section{Results}

Five hundred one eyes of 283 AQP4-IgG-seropositive patients and 136 eyes of 72 HCs were included in the analysis (Table 1).

\section{Neuroaxonal Damage After ON}

GCIP layer and pRNFL were reduced in NMOSD-ON compared with NMOSD eyes without a history of $\mathrm{ON}$
(NMOSD-NON) and HC (GCIP layer: $81.4 \pm 5.7 \mu \mathrm{m}$, pRNFL: $101.1 \pm 9.0 \mu \mathrm{m}$ ) (Figures $1 \mathrm{~A}$ and 2A; Tables 2 and 3). The absolute (GCIP layer: $-22.7 \mu \mathrm{m}$; pRNFL: $-38.5 \mu \mathrm{m}$ ) and relative (GCIP layer: $-38.8 \%$; pRNFL: $-61.6 \%$ ) loss in eyes with $1 \mathrm{ON}$ episode (NMOSD-1-ON) compared with NMOSD-NON was higher than in eyes with $2 \mathrm{ON}$ episodes (NMOSD-2-ON) compared with NMOSD-1-ON (GCIP layer absolute loss: $-3.5 \mu \mathrm{m}$, relative loss: $-6.0 \%$; $\mathrm{pRNFL}$ absolute loss: $-9.1 \mu \mathrm{m}$, relative loss: $-14.5 \%$, n.s.). The loss in 
Table 2 Group Comparisons of GCIP Layer Thickness for Heidelberg SD-OCT

\begin{tabular}{|c|c|c|c|c|c|c|c|c|c|c|c|}
\hline & $\begin{array}{l}\text { No. of } \\
\text { eyes }\end{array}$ & $\begin{array}{l}\text { Thickness }(\mu \mathrm{m}, \\
\text { mean } \pm S D)\end{array}$ & $\begin{array}{l}\text { Comparison } \\
\text { to }\end{array}$ & $\begin{array}{l}\text { Absolute } \\
\text { difference ( } \mu \mathrm{m}, \\
\text { mean) }\end{array}$ & $\begin{array}{l}\text { Relative } \\
\text { difference }(\% \text {, } \\
\text { mean) }\end{array}$ & B & SE & $p$ Value & $\mathbf{R}_{\text {marg }}^{2}$ & $\mathbf{R}_{\text {cond }}^{2}$ & $\begin{array}{l}\text { Combined } \\
p \text { value }\end{array}$ \\
\hline NMOSD & 268 & $67.3 \pm 13.6$ & $\mathrm{HCS}$ & -14.0 & -20.8 & 15.6 & 2.0 & $<0.0001$ & 0.143 & 0.690 & - \\
\hline $\begin{array}{l}\text { NMOSD- } \\
\text { ON }\end{array}$ & 124 & $57.4 \pm 12.2$ & & -24.0 & -41.8 & 25.0 & 2.0 & $<0.0001$ & 0.482 & 0.839 & - \\
\hline $\begin{array}{l}\text { NMOSD- } \\
\text { NON }\end{array}$ & 144 & $75.9 \pm 7.7$ & & -5.4 & -7.2 & 5.8 & 1.4 & $<0.0001$ & 0.088 & 0.947 & - \\
\hline $\begin{array}{l}\text { NMOSD- } \\
\text { NON }_{\text {non }}\end{array}$ & 99 & $77.3 \pm 5.9$ & & -4.0 & -5.0 & 2.69 & 1.42 & 0.061 & 0.189 & 0.924 & - \\
\hline $\begin{array}{l}\text { NMOSD- } \\
\text { NON }_{\text {con }}\end{array}$ & 45 & $72.9 \pm 10.2$ & & -8.5 & -10.4 & 8.44 & 1.77 & $<0.0001$ & 0.260 & 0.985 & - \\
\hline $\begin{array}{l}\text { NMOSD- } \\
\text { ON }\end{array}$ & 124 & $57.4 \pm 12.2$ & $\begin{array}{l}\text { NMOSD- } \\
\text { NON }\end{array}$ & -18.5 & -24.4 & -15.8 & 1.1 & $<0.0001$ & 0.430 & 0.795 & $5.9 e^{-45}$ \\
\hline $\begin{array}{l}\text { NMOSD-1- } \\
\text { ON }\end{array}$ & 76 & $58.6 \pm 12.9$ & & -17.3 & -22.8 & -14.5 & 1.2 & $<0.0001$ & 0.417 & 0.803 & $1.4 e^{-33}$ \\
\hline $\begin{array}{l}\text { NMOSD-2- } \\
\text { ON }\end{array}$ & 28 & $55.1 \pm 9.4$ & $\begin{array}{l}\text { NMOSD-1- } \\
\text { ON }\end{array}$ & -3.5 & -6.0 & -5.7 & 2.6 & 0.028 & 0.143 & 0.729 & 0.038 \\
\hline $\begin{array}{l}\text { NMOSD- } \\
\geq 3-\text { ON }\end{array}$ & 20 & $55.9 \pm 12.8$ & $\begin{array}{l}\text { NMOSD-2- } \\
\text { ON }\end{array}$ & 0.8 & 1.4 & 4.9 & 2.6 & 0.070 & 0.311 & 0.781 & 0.222 \\
\hline $\begin{array}{l}\text { NMOSD- } \\
\text { NON }_{\text {con }}\end{array}$ & 45 & $72.9 \pm 10.2$ & $\begin{array}{l}\text { NMOSD- } \\
\text { NON non }^{-}\end{array}$ & -4.4 & -6.1 & -3.8 & 1.7 & 0.025 & 0.111 & 0.701 & 0.004 \\
\hline $\begin{array}{l}\text { NMOSD- } \\
\text { NON }_{\text {1-con }}\end{array}$ & 37 & $73.6 \pm 9.4$ & & -3.7 & -5.1 & -3.5 & 1.6 & 0.037 & 0.149 & 0.906 & 0.154 \\
\hline
\end{tabular}

Abbreviations: AQP4-IgG = aquaporin-4 IgG; B = estimate; GCIP = ganglion cell and inner plexiform; NMOSD = AQP4-IgG-seropositive NMOSD; NMOSD-NON =

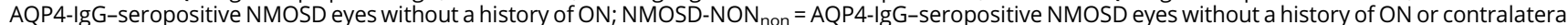
ON; NMOSD-NON ${ }_{\text {con }}=$ AQP4-IgG-seropositive NMOSD eyes without a history of ON but with a history of contralateral ON; NMOSD-NON 1 -con $=$ AQP4IgG-seropositive NMOSD eyes without a history of ON but with a history of 1 contralateral ON; NMOSD-ON = AQP4-IgG-seropositive NMOSD eyes with a history of ON; NMOSD-1-ON = AQP4-IgG-seropositive NMOSD eyes with a history of 1 ON; NMO-2-ON = AQP4-IgG-seropositive NMOSD eyes with a history of 2 ONs; NMOSD- $\geq 3-O N=$ AQP4-IgG-seropositive NMOSD eyes with a history of 3 or more ONs; NMOSD = neuromyelitis optica spectrum disorder; NMOSDNON = NMOSD eyes without a history of ON; OCT = optical coherence tomography; ON = optic neuritis episode; Rcon = conditional R-squared; Rmarg = marginal R-squared; SE = standard error.

eyes with $\geq 3$-ON episodes (NMOSD-3-ON) was lower compared with NMOSD-2-ON (n.s.) (Figures $1 \mathrm{~B}$ and $2 \mathrm{~B}$ ). Five NMOSD-NON eyes had pRNFL values $<60 \mu \mathrm{m}$; these patients had no relevant comorbidities but a history of contralateral ON. ${ }^{17,18}$ In sensitivity analyses to account for device differences, all significant analyses within the NMOSD cohort were confirmed for data acquired by Cirrus and Topcon OCT devices (eFigures 2 and 3; eTables 3 and 4, links.lww.com/ NXI/A556; links.lww.com/NXI/A557).

\section{Neuroaxonal Damage Without ON}

NMOSD-NON eyes had a reduced GCIP layer $(75.9 \pm 7.7 \mu \mathrm{m}$, $p<0.001)$, but not pRNFL $(95.3 \pm 14.4 \mu \mathrm{m})$ compared with HC (GCIP layer: $81.4 \pm 5.7 \mu \mathrm{m}$, pRNFL: $101.1 \pm 9.0 \mu \mathrm{m}$; Figures 1A and 2A; Tables 2 and 3). By comparison, only 28 NMOSDNON eyes (5.1\%) had a GCIP layer $\leq$ the 5th percentile of HC. GCIP layer was also reduced in NMOSD-NON with a history of contralateral ON $(72.9 \pm 10.2 \mu \mathrm{m})$ compared with NMOSDNON without a history of contralateral ON $(77.3 \pm 5.9 \mu \mathrm{m}, p=$ $0.025, \mathrm{NMOSD}^{-N_{O N}} \mathrm{non}_{\text {no }}$ ). This effect vanished when only considering NMOSD-NON $\mathrm{N}_{\text {con }}$ with a history of 1 contralateral ON $(73.6 \pm 9.4 \mu \mathrm{m})$. However, only NMOSD-NON ${ }_{\text {con }}(p<$
$0.001)$ but not NMOSD-NON ${ }_{\text {non }}(p=0.061)$ had thinned GCIP layer compared with HC (Figures 1C and 2C).

\section{INL Changes}

INL was thicker in NMOSD-ON compared with HC (39.4 \pm $2.6 \mu \mathrm{m}$ ) and NMOSD-NON (eTable 4, links.lww.com/NXI/ A557). Specifically, INL was thicker in eyes with $1 \mathrm{ON}$ episode compared with NMOSD-NON but did not differ between eyes with different numbers of ON episodes. Also, INL did not differ between NMOSD-NON $\mathrm{Con}_{\mathrm{con}}(38.9 \pm 3.2 \mu \mathrm{m})$ and NMOSD$\mathrm{NON}_{\text {non }}(38.5 \pm 3.2 \mu \mathrm{m}, p=0.931)$. In all patients, INL thickness (as the dependent variable in the linear mixed model described above) was correlated with thinner GCIP layer ( $\mathrm{B}=$ -0.11 , standard error $[\mathrm{SE}]=0.01, p<0.001)$ and $\mathrm{pRNFL}(\mathrm{B}=$ $-0.06, \mathrm{SE}=0.01, p<0.001)$. This correlation existed in NMOSD-ON (GCIP layer: $\mathrm{B}=-0.08, \mathrm{SE}=0.03, p=0.005$; pRNFL: $\mathrm{B}=-0.06, \mathrm{SE}=0.01, p<0.001)$ and not present in NMOSD-NON (eFigure 4, links.lww.com/NXI/A556).

Scans of 363 NMOSD eyes were clearly suitable for MME investigations (high quality, eFigure 4C, links.lww.com/NXI/ A556). MMEs were visible in $24(6.6 \%)$ eyes of 21 patients. 
Table 3 Group Comparisons of pRNFL Thickness With (A) Spectralis SD-OCT Data for Comparisons vs HC (B) Data From All Devices for Intrapatient Cohort Comparisons

\begin{tabular}{|c|c|c|c|c|c|c|c|c|c|c|c|}
\hline & $\begin{array}{l}\text { No. of } \\
\text { eyes }\end{array}$ & $\begin{array}{l}\text { Thickness }(\mu \mathrm{m}, \\
\text { mean } \pm \text { SD })\end{array}$ & $\begin{array}{l}\text { Comparison } \\
\text { to }\end{array}$ & $\begin{array}{l}\text { Absolute difference } \\
\text { ( } \mu \mathrm{m}, \text { mean) }\end{array}$ & $\begin{array}{l}\text { Relative } \\
\text { difference (\%, } \\
\text { mean) }\end{array}$ & B & SE & $p$ Value & $\mathbf{R}_{\text {marg }}^{2}$ & $\mathbf{R}_{\text {cond }}^{2}$ & $\begin{array}{l}\text { Combined } \\
p \text { value }\end{array}$ \\
\hline NMOSD & 344 & $76.3 \pm 27.4$ & $\mathrm{HCs}$ & -14.0 & -32.6 & 24.2 & 4.3 & $<0.0001$ & 0.143 & 0.690 & - \\
\hline $\begin{array}{l}\text { NMOSD- } \\
\text { ON }\end{array}$ & 170 & $56.9 \pm 23.7$ & & -44.3 & -77.9 & 43.1 & 4.1 & $<0.0001$ & 0.482 & 0.839 & - \\
\hline $\begin{array}{l}\text { NMOSD- } \\
\text { NON }\end{array}$ & 174 & $95.3 \pm 14.4$ & & -5.9 & -6.2 & 4.6 & 3.0 & 0.129 & 0.088 & 0.947 & - \\
\hline $\begin{array}{l}\text { NMOSD- } \\
\text { NON }_{\text {non }}\end{array}$ & 116 & $97.4 \pm 10.9$ & & -3.7 & -3.7 & -2.9 & 2.2 & 0.204 & 0.107 & 0.893 & - \\
\hline $\begin{array}{l}\text { NMOSD- } \\
\text { NON }_{\text {con }}\end{array}$ & 58 & $91.0 \pm 19.1$ & & -4.7 & -4.6 & 7.1 & 4.2 & 0.097 & 0.100 & 0.975 & - \\
\hline $\begin{array}{l}\text { NMOSD- } \\
\text { ON }\end{array}$ & 170 & $56.9 \pm 23.7$ & $\begin{array}{l}\text { NMOSD- } \\
\text { NON }\end{array}$ & -38.4 & -40.3 & -33.8 & 2.1 & $<0.0001$ & 0.436 & 0.741 & $4.4 e^{-60}$ \\
\hline $\begin{array}{l}\text { NMOSD-1- } \\
\text { ON }\end{array}$ & 97 & $62.6 \pm 24.9$ & & -32.7 & -34.3 & -29.6 & 2.2 & $<0.0001$ & 0.379 & 0.712 & $4.6 e^{-40}$ \\
\hline $\begin{array}{l}\text { NMOSD-2- } \\
\text { ON }\end{array}$ & 35 & $53.5 \pm 21.3$ & $\begin{array}{l}\text { NMOSD-1- } \\
\text { ON }\end{array}$ & -9.1 & -14.5 & -10.7 & 4.7 & 0.024 & 0.087 & 0.528 & 0.010 \\
\hline $\begin{array}{l}\text { NMOSD- } \\
\geq 3-O N\end{array}$ & 38 & $45.2 \pm 17.8$ & $\begin{array}{l}\text { NMOSD-2- } \\
\text { ON }\end{array}$ & -8.3 & -15.5 & -0.4 & 4.3 & 0.924 & 0.087 & 0.719 & 0.838 \\
\hline $\begin{array}{l}\text { NMOSD- } \\
\text { NON }_{\text {con }}\end{array}$ & 58 & $91.0 \pm 19.1$ & $\begin{array}{l}\text { NMOSD- } \\
\text { NON }_{\text {non }}\end{array}$ & -6.5 & -7.1 & -4.0 & 2.9 & 0.173 & 0.061 & 0.939 & 0.157 \\
\hline $\begin{array}{l}\text { NMOSD- } \\
\text { NON }_{1-\text { con }}\end{array}$ & 47 & $93.2 \pm 18.1$ & & -4.2 & -4.6 & -3.2 & 2.9 & 0.276 & 0.056 & 0.925 & 0.616 \\
\hline
\end{tabular}

Abbreviations: AQP4-IgG = aquaporin-4 IgG; NMOSD = AQP4-IgG-seropositive NMOSD; NMOSD-NON = AQP4-IgG-seropositive NMOSD eyes without a history of ON; NMOSD-NONnon = AQP4-IgG-seropositive NMOSD eyes without a history of ON or contralateral ON; NMOSD-NON seropositive NMOSD eyes without a history of ON but with a history of contralateral ON; NMOSD-NON con $=$ AQP4-IgG-seropositive NMOSD eyes without a history of ON but with a history of 1 contralateral ON; NMOSD-ON = AQP4-IgG-seropositive NMOSD eyes with a history of ON; NMOSD-1-ON = AQP4IgG-seropositive NMOSD eyes with a history of 1 ON; NMOSD-2-ON = AQP4-IgG-seropositive NMOSD eyes with a history of 2 ONs; NMOSD- $\geq 3-O N=$ AQP4IgG-seropositive NMOSD eyes with a history of 3 or more ONs; NMOSD = neuromyelitis optica spectrum disorder; NMOSD-NON = NMOSD eyes without a history of ON; OCT = optical coherence tomography; ON = optic neuritis episode; pRNFL = peripapillary retinal nerve fiber layer; VEP = visually evoked potential.

Twenty-three eyes (13.1\%) of NMOSD-ON and 1 eye (0.5\%) of NMOSD-NON (with a history of contralateral ON) were affected. The number of $\mathrm{ON}$ episodes did not influence the incidence of MMEs (NMOSD-1-ON N = 16 (14\%), NMOSD$2-\mathrm{ON} \mathrm{N}=4(11.4 \%), \mathrm{NMOSD}-23-\mathrm{ON} \mathrm{N}=3(11.1 \%)$ ).

Including only the most frequent ethnicities in our data set (Asian and non-Hispanic White), results did not differ, and no ethnicity was singled out regarding its pattern of injury (data not shown).

\section{OCT and Vision Loss}

HC-VA was numerically reduced in NMOSD $(0.25 \pm 0.48)$ compared with $\mathrm{HC}(-0.01 \pm 0.08)$ and known healthy reference values. NMOSD-ON also had reduced HC-VA $(0.44 \pm 0.58)$ compared with NMOSD-NON $(0.04 \pm 0.20, p<0.001, p=$ 0.401 ) and $\mathrm{HC} /$ healthy reference populations. HC-VA was correlated with GCIP layer $(\mathrm{B}=-0.016, \mathrm{SE}=0.002, p<0.001)$ and pRNFL thicknesses $(\mathrm{B}=-0.010, \mathrm{SE}=0.001, p<0.001)$ in AQP4-IgG-seropositive NMOSD. AQP4-IgG-seropositive NMOSD eyes with prolonged VEP latency had a thinned GCIP layer $(\mathrm{B}=-11.647, \mathrm{SE}=3.628, p=0.002)$ and $\mathrm{pRNFL}(\mathrm{B}=$ $-21.965, \mathrm{SE}=3.724, p<0.001)$. EDSS score as a metric of global disability was inversely correlated with GCIP layer $(\mathrm{B}=-1.370$, $\mathrm{SE}=0.566, p=0.017)$ and $p R N F L$ thicknesses $(\mathrm{B}=-3.148, \mathrm{SE}=$ $1.080, p=0.004)$.

\section{Discussion}

Our study specifies a severe and functionally relevant decrease of GCIP layer and pRNFL in NMOSD-ON compared with NMOSD-NON and HCs in AQP4-IgG-seropositive patients. Neuroaxonal damage is particularly large from the first episode of $\mathrm{ON}$, where contribution to retinal damage in subsequent episodes of $\mathrm{ON}$ is still considerable but smaller. In contrast to previous smaller studies, the current study ascertains GCIP layer but not pRNFL thinning in NMOSD-NON compared with HC. ${ }^{6,19}$ This effect was driven by eyes with contralateral $\mathrm{ON}$ and not statistically significant in eyes without a history of ON. INL was thicker in NMOSD-ON and was inversely correlated with GCIP layer. Of note, $13.1 \%$ 
of NMOSD-ON eyes showed MME indicative of secondary inflammatory changes. ${ }^{20,21}$ This investigation overcame limits of small samples and OCT data heterogeneity of earlier studies through use of an international consortium of NMOSD specialists. This framework substantiated the CROCTINO study-a large, multicenter, retrospective evaluation of retinal pathology in NMOSD using OCT.

The neuroaxonal degeneration in NMOSD-ON demonstrated here is substantially greater than reported changes in multiple sclerosis (MS), a common differential diagnosis. ${ }^{2,22}$ In a meta-analysis, an average pRNFL loss of $20 \mu \mathrm{m}$ was estimated in MS after ON, which is nearly 2 -fold higher in our NMOSD-ON cohort $(-38.4 \mu \mathrm{m}){ }^{22}$ For GCIP layer, our data suggested approximately 1.5 -fold higher loss in NMOSD $(-24.0 \mu \mathrm{m})$ compared with MS. ${ }^{22}$ These differences not only result from a higher $\mathrm{ON}$ frequency, but may also be caused by more severe retinal damage in NMOSD after a singular $\mathrm{ON}^{23}$ It is intriguing that the damage is particularly large after the first ON episode with smaller losses after subsequent episodes, which might be due to less neuroaxonal content in subsequent episodes. ${ }^{2,24}$ Alternatively, although the analysis of treatment effects exceeds the scope of this study, it is possible that the longer time to effective anti-inflammatory therapy and the typical choice of less effective therapies (e.g., steroids instead of plasma exchange) at the first attack compared with following attacks may significantly contribute to this difference. Independent of the number of ONs, the percent loss is smaller in GCIP layer compared with pRNFLpointing toward either (1) stronger loss of retinal nerve fibers than retinal ganglion cells, (2) impairment of ganglion cells not leading to extinction but axonal loss; (3) a larger amount of non-neuronal tissue in GCIP layer, or (4) RNFL loss in the periphery beyond the macular area measured by GCIP layer. These hypotheses are not mutually exclusive, and each might contribute to the effect. Consistent with these concepts, excessive vision loss relative to neuroaxonal content and VEP latency in AQP4-IgG-seropositive patients compared with MOG-IgG-seropositive and MS patients implies damage of the peripheral retina and optic nerve tissues, which are not reflected in the macula and pattern VEP measurements. ${ }^{4}$

Whether attack-independent neurodegeneration in AQP4-IgG-seropositive NMOSD occurs has been controversial. $^{2,6,7,25-28}$ The current study identifies decreased GCIP layer in NMOSD-NON compared with HC, but not pRNFL. Such subclinical changes could be caused by contralateral involvement after unilateral ON. ${ }^{17,18}$ Indeed, our cohort suggests pronounced neurodegeneration in eyes with contralateral ON. However, eyes of patients without $\mathrm{ON}$ also exhibit a trend for thinner GCIP layer compared with HCs. Underscored by longitudinal studies showing $\mathrm{ON}$-independent neurodegeneration and VEP latency prolongation, ${ }^{7,29}$ such patterns suggest at least 2 mechanisms of injury: (1) a primary retinopathy or optic neuropathy in context of an astrocytopathy or caused by direct damage to AQP4-expressing cells such as astrocytes and Müller cells by either AQP4-IgG or AQP4-specific $\mathrm{T}$ cells or (2) a global or afferent visual system specific chronic or episodic neurodegenerative process. Because lesions often spare the brain, and most studies outside of predisposed areas such as optic nerve and spinal cord failed to detect effects, ${ }^{30}$ a constant global involvement seems unlikely. Several studies described changes affecting AQP4 expression and astrocytic end feet, ${ }^{31}$ parafoveal changes in agreement with an involvement of AQP4-expressing Müller cell, $^{6,26,27,32}$ and attack-independent spinal cord atrophy. ${ }^{33}$ These findings are consistent with tissue infiltration by AQP4-IgG-specific $\mathrm{T}$ cells ${ }^{34}$ and the attack-independent loss of retinal ganglion cells ${ }^{7}$-further supporting the existence of an $\mathrm{ON}$-independent pathology, which might be restricted to the main disease foci. The latter hypotheses could be addressed by region-specific pathology or advanced imaging studies.

INL changes have been suggested as a marker of neuroinflammation and potential treatment response in MS. ${ }^{21,35,36}$ MME may develop as a consequence of neurodegeneration or other-non-disease-specific-processes. ${ }^{35}$ Patients with NMOSD were described to have INL thickening and MME. $^{20,37}$ In our cohort, $13.1 \%$ of NMOSD-ON eyes were affected by MME, which is higher than the $2 \%-5 \%$ described in MS but comparable to incidences in NMOSD described before by Gelfand and colleagues. ${ }^{35,37}$ However, INL thickening itself remained comparable to changes reported in MS. ${ }^{35}$ This disparity could reflect a disrupted fluid homeostasis due to Müller cell involvement or loss of content of the INL with a parallel inflammatory reaction and development of MME. The limited accessibility of MMEs, especially in severely affected eyes due to limited image quality, has hindered their detailed assessments and most likely leads to underestimation of their incidence. ${ }^{38}$ We demonstrate that the INL thickness is inversely correlated with neuroaxonal content and could be a valuable marker of disease severity also in NMOSD.

Our study cohort was representative of patients with AQP4IgG-seropositive NMOSD with respect to a female predominance and ON history. ${ }^{11,39}$ This OCT study included multiple ethnicity backgrounds, although the distribution was shifted toward Caucasian/White patients and other ethnicities were underrepresented (e.g., Hispanic White and Black), limiting the generalizability of results. ${ }^{40}$ Patients from different heritages presented similar findings.

The current study was based on source data instead of a metaanalysis. Using the Guthy-Jackson Charitable Foundation network, this multicentric study was conducted without investigator reimbursement and illustrated how collaboration integrating international perspectives can produce meaningful results. To overcome technical challenges of heterogeneous source data, we developed novel OCT postprocessing techniques allowing us to perform standardized analyses and enabling the uniform analysis of the largest OCT image data set in NMOSD to date. ${ }^{10}$ Thus, the strengths of CROCTINO include its established 
infrastructure, large international network of experts representing multiple ethnicities and geographic regions, and the use of state-of-the-art OCT postprocessing techniques. ${ }^{41}$

We recognize limitations of the current investigation: The retrospective and heterogeneous data acquisition might have led to biases and impreciseness beyond the ability of our quality control. We addressed this by excluding uncertain cases. HCs were only included from a limited number of centers. The unbalanced data set limited some analyses, such as the influence of ethnicities or acute and disease-modifying treatments. Case-control matching was impossible, particularly with respect to subclinical progression dependent or independent of ON and to ethnicity. Similarly, comparisons with other NMOSD subtypes or MS were beyond the scope of this study. Longitudinal data, acute ON data, and AQP4IgG-seronegative and MOG-IgG-seropositive patient data are part of the CROCTINO data set and will be analyzed in the future. Also, OCT data processing was performed by multiple raters potentially introducing interrater variability. MRI data and posterior visual pathway involvement were not investigated in this study. However, the current study achieved an unprecedented worldwide assessment of retinal damage in AQP4-IgG-seropositive NMOSD.

To conclude, AQP4-IgG-seropositive NMOSD is characterized by a severe, functionally relevant retinal neurodegeneration as a consequence of $\mathrm{ON}$. Although the majority of damage occurs during the first episode, there is cumulative loss with each succeeding relapse. The $\mathrm{ON}$-associated damage is not limited to the neuroaxonal content but can also induce-likely inflammationmediated-INL increase and occurrence of MME. Our data also suggest attack-independent retinal damage in AQP4IgG-seropositive NMOSD. Our study supports that attack prevention is key in avoiding neuroaxonal damage and vision loss in patients with NMOSD. It further suggests that the first $\mathrm{ON}$ episode causes the most damage, where only some patients with then established diagnosis will be on immunosuppressive therapy. This highlights the need for effective therapies that can ameliorate an ongoing attack or regenerate attack-generated damage, which is an unmet clinical need. Last, the study emphasizes the utility of OCT as a sensitive structural metric and its potential for monitoring progression and even treatment response in AQP4IgG-seropositive NMOSD. The international CROCTINO program provides an unprecedented opportunity to apply OCT in a standardized manner to assess pathophysiology, clinical course, and therapeutic efficacy in NMOSD.

\section{Study Funding}

Guthy-Jackson Charitable Foundation (GJCF) and German Research Foundation (DFG).

\section{Disclosure}

F.C. Oertel was employee of Nocturne $\mathrm{GmbH}$ and receives research support by the American Academy of Neurology and the National Multiple Sclerosis Society, unrelated to this work.
S. Specovius reports no disclosures. H.G. Zimmerman reports research grants from Novartis and speaking honoraria from Bayer Healthcare, unrelated to this study. C. Chien reports speaking honoraria from Bayer Healthcare, unrelated to this work. S. Motamedi and C. Bereuter report no disclosures. L. Cook reports grants from Guthy Jackson Charitable Foundation, during the conduct of the study. E.H. Martinez-Lapiscina is employed by the European Medicines Agency (Human Medicines) since 16 April 2019. This article is related with her activity under Hospital Clinic of Barcelona/IDIBAPS affiliation and consequently, as external activity, it does not represent the views of the Agency, its Committees or working parties. Before enrolling EMA, Dr. Martinez-Lapiscina reports grants from Instituto de Salud Carlos III (Spain) \& Fondo Europeo de Desarrollo Regional, grants from MS Innovation GMSI, other from Fundació Privada Cellex, and personal fees from Novartis, Roche, Sanofi-Genzyme, outside the submitted work. M.A. Lana Peixoto and M.A. Fontanelle report no disclosures. H.J. Kim reports grants from the National Research Foundation of Korea, personal fees from Alexion Pharmaceuticals, Aprilbio, Biogen, Celltrion, Eisai, HanAll BioPharma, MDimune, Merck Serono, Novartis, Sanofi Genzyme, Teva-Handok, and Viela Bio, other from Viela Bio (formerly MedImmune), Multiple Sclerosis Journal, and Journal of Clinical Neurology, outside the submitted work. J.-W. Hyun reports grants from the National Research Foundation of Korea, outside the submitted work. J. Palace reports personal fees from Abide Therapeutics, Alexion Pharmaceuticals, ARGENX, Bayer Schering, Biogen Idec, Chugai Pharma, EuroImmun, Genzyme, MedDay, MedImmune, Merck Serono, Novartis, Roche, Teva, UCB, and Viela Bio; grants from Abide Therapeutics, Alexion Pharmaceuticals, Bayer Schering, Biogen Idec, Chugai Pharma, Genzyme, MedImmune, Merck Serono, Novartis, and Teva, grants from Merck Serono, Novartis, Biogen Idec, Teva, Abide, MedImmune, Bayer Schering, Genzyme, Chugai and Alexion; Eugène Devic European Network, the Grant for Multiple Sclerosis Innovation, the John Fell Fund, the Medical Research Council, the MS Society, Myaware, the UK National Institute for Health Research, Oxford Health Services Research Committee, and the Guthy-Jackson Charitable Foundation AMPLO and SPARKS Great Ormond Street, for research studies outside the submitted work. M.I. Leite and S. Sharma report no disclosures. A. Roca-Fernandez is sponsored by Abide Therapeutic outside of the submitted work and reports no potential conflicts of interest. R. Kafieh, A. Dehghani, M. Pourazizi, L. Pandit and A. D'Cunha report no disclosures. O. Aktas reports grants from German Research Foundation (DFG) and German Ministry of Education and Research (BMBF); personal fees from Alexion and Almirall; grants and personal fees from Biogen, personal fees from Merck, grants and personal fees from Novartis, grants and personal fees from Roche, personal fees from Sanofi, personal fees from Teva, personal fees from Viela Bio, outside the submitted work. M. Ringelstein received speaker honoraria from Novartis, Bayer Vital GmbH, Roche, Alexion and Ipsen and travel reimbursement from Bayer Schering, Biogen Idec, Merz, Genzyme, Teva, Roche, and Merck, none related to this study. P. Albrecht reports grants, 
personal fees and non-financial support from Allergan, Biogen, Merck, Merz Pharmaceuticals, Novartis, Ipsen, Celgene, Roche, and personal fees and non-financial support from Teva outside the submitted work. E. May and C. Tongco report no disclosures. L. Leocani reports personal fees from Roche, Merck, Bristol Myers Squibb, and Med-ex learning, outside the submitted work. M. Pisa reports no disclosures. M. Radaelli reports personal fees from Merck Serono, Sanofi-Genzyme, Novartis, and Biogen, outside the submitted work. H. StiebelKalish reports no disclosures. S. Siritho reports personal fees from Novartis, Thailand, Biogen Idec, Eisai Thailand marketing co. 1td., Merck Serono, Teva Thailand, and Menarini, outside the submitted work. J. de Seze and T. Senger report no disclosures. J. Havla reports grants, personal fees and non-financial support from Merck, personal fees from Novartis, Celgene, Roche, Santhera, Biogen, Alexion, Sanofi, non-financial support from Guthy-Jackson Charitable Foundation, and grants from Friedrich Baur Foundation, outside the submitted work. R. Marignier, A.C. Calvo, D. Bichuetti, I.M. Tavares, N. Asgari, K. Soelberg, A. Altintas, R. Yildirim, U. Tanriverdi, A. Jacob, S. Huda, Z. Rimler and A. Reid report no disclosures. Y. MaoDraayer reports grants from NIH NIAID, grants and personal fees from Genzyme, grants from Chugai, personal fees from Biogen and EMD Serono, grants and personal fees from Genentech and Novartis, during the conduct of the study; grants from NIH NIAID, grants and personal fees from Genzyme, grants from Chugai, personal fees from Biogen and EMD Serono, grants and personal fees from Genentech and Novartis, outside the submitted work. I. Soto de Castillo reports no disclosures. A. Petzold reports personal fees and grants from Novartis, outside the submitted work, and is part of the steering committee of the OCTiMS study which is sponsored by Novartis. He has not received honoraria for this activity. A.J. Green reports other from Bionure, grants, personal fees and other from Inception Sciences, grants from Sherak Foundation, personal fees and other from Pipeline Pharmaceuticals, grants from Hilton Foundation, Adelson Foundation, and National MS Society, personal fees from JAMA Neurology, personal fees and other from Mediimmune/Viela, outside the submitted work. In addition, Dr. Green has a patent Small Molecule drug for Remyelination pending and has worked on testing off label compounds for remyelination. M.R. Yeaman serves as an advisor to the Guthy-Jackson Charitable Foundation. T. Smith reports no disclosures. A.U. Brandt reports grants from the Guthy Jackson Charitable Foundation during the conduct of the study; shares from Motognosis $\mathrm{GmbH}$ and shares from Nocturne GmbH outside the submitted work. In addition, Dr. Brandt has a patent pending describing Foveal Morphometry. F. Paul reports grants from the Guthy Jackson Charitable Foundation, during the conduct of the study; grants from the German Research Foundation and German Federal Ministry of Education and research, grants, and other from Novartis, grants and other from Bayer, Novartis, Biogen Idec, Teva, SanofiAventis/Genzyme, Merck Serono, Chugai, other from PLoS ONE, other from Neurology ${ }^{\circledR}$ Neuroimmunology \& Neuroinflammation, other from SanofiGenzyme, Biogen Idec, grants from German Research Council, Werth Stiftung of the City of
Cologne, German Ministry of Education and Research, Arthur Arnstein Stiftung Berlin, EU FP7 Framework Program, Arthur Arnstein Foundation Berlin, National Multiple Sclerosis (USA), other from MedImmune, Shire, Alexion, outside the submitted work. In addition, Dr. Paul has a patent Foveal Morphometry pending to Nocturne GmbH. Go to Neurology. org/NN for full disclosures.

\section{Publication History}

Received by Neurology: Neuroimmunology \& Neuroinflammation March 23, 2021. Accepted in final form June 15, 2021.

\section{Appendix Authors}

\begin{tabular}{|c|c|c|}
\hline Name & Location & Contribution \\
\hline $\begin{array}{l}\text { Frederike Cosima } \\
\text { Oertel, MD/PhD }\end{array}$ & $\begin{array}{l}\text { Experimental and Clinical } \\
\text { Research Center, Max } \\
\text { Delbrück Center for } \\
\text { Molecular Medicine and } \\
\text { Charité-Universitätsmedizin, } \\
\text { Corporate Member of Freie } \\
\text { Universität Berlin and } \\
\text { Humboldt-Universität zu } \\
\text { Berlin, Germany }\end{array}$ & $\begin{array}{l}\text { Acquisition and } \\
\text { analysis of data and } \\
\text { drafting a significant } \\
\text { portion of the } \\
\text { manuscript or figures; } \\
\text { conception and design } \\
\text { of the study }\end{array}$ \\
\hline
\end{tabular}

\begin{tabular}{ll}
\hline Svenja Specovius, & Experimental and Clinical \\
MSc & Research Center, Max \\
& Delbrück Center for \\
& Molecular Medicine and \\
& Charité-Universitätsmedizin, \\
& Corporate Member of Freie \\
& Universität Berlin and \\
& Humboldt-Universität zu \\
& Berlin, Germany
\end{tabular}

Acquisition and analysis of data; conception and design of the study

\begin{tabular}{ll}
\hline Hanna G & Experimental and Clinical \\
Zimmermann, & Research Center, Max \\
PhD & Delbrück Center for \\
& Molecular Medicine and \\
& Charité-Universitätsmedizin, \\
& Corporate Member of Freie \\
& Universität Berlin and \\
& Humboldt-Universität zu \\
& Berlin, Germany
\end{tabular}

\begin{tabular}{|c|c|c|}
\hline $\begin{array}{l}\text { Claudia Chien, } \\
\text { PhD }\end{array}$ & $\begin{array}{l}\text { Experimental and Clinical } \\
\text { Research Center, Max } \\
\text { Delbrück Center for } \\
\text { Molecular Medicine and } \\
\text { Charité-Universitätsmedizin, } \\
\text { Corporate Member of Freie } \\
\text { Universität Berlin and } \\
\text { Humboldt-Universität zu } \\
\text { Berlin, Germany }\end{array}$ & $\begin{array}{l}\text { Acquisition and } \\
\text { analysis of data }\end{array}$ \\
\hline $\begin{array}{l}\text { Seyedamirhosein } \\
\text { Motamedi, PhD }\end{array}$ & $\begin{array}{l}\text { Experimental and Clinical } \\
\text { Research Center, Max } \\
\text { Delbrück Center for } \\
\text { Molecular Medicine and } \\
\text { Charité-Universitätsmedizin, } \\
\text { Corporate Member of Freie } \\
\text { Universität Berlin and } \\
\text { Humboldt-Universität zu } \\
\text { Berlin, Germany }\end{array}$ & $\begin{array}{l}\text { Acquisition and } \\
\text { analysis of data }\end{array}$ \\
\hline $\begin{array}{l}\text { Charlotte } \\
\text { Bereuter, BSc }\end{array}$ & $\begin{array}{l}\text { Experimental and Clinical } \\
\text { Research Center, Max } \\
\text { Delbrück Center for } \\
\text { Molecular Medicine and } \\
\text { Charité-Universitätsmedizin, } \\
\text { Corporate Member of Freie } \\
\text { Universität Berlin and } \\
\text { Humboldt-Universität zu } \\
\text { Berlin, Germany }\end{array}$ & $\begin{array}{l}\text { Acquisition and } \\
\text { analysis of data }\end{array}$ \\
\hline
\end{tabular}

Acquisition and analysis of data; conception and design of the study 
Appendix (continued)

\begin{tabular}{|c|c|c|}
\hline Name & Location & Contribution \\
\hline $\begin{array}{l}\text { Lawrence Cook, } \\
\text { PhD }\end{array}$ & $\begin{array}{l}\text { University of Utah, } \\
\text { Salt Lake City, UT }\end{array}$ & $\begin{array}{l}\text { Acquisition and } \\
\text { analysis of data and } \\
\text { conception and design } \\
\text { of the study }\end{array}$ \\
\hline $\begin{array}{l}\text { Marco Aurélio } \\
\text { Lana Peixoto, MD, } \\
\text { PhD }\end{array}$ & $\begin{array}{l}\text { University of Minas Gerais, } \\
\text { Medical School, Belo } \\
\text { Horizonte, Brazil }\end{array}$ & $\begin{array}{l}\text { Acquisition and } \\
\text { analysis of data }\end{array}$ \\
\hline $\begin{array}{l}\text { Mariana Andrade } \\
\text { Fontanelle, MD }\end{array}$ & $\begin{array}{l}\text { University of Minas Gerais, } \\
\text { Medical School, Belo } \\
\text { Horizonte, Brazil }\end{array}$ & $\begin{array}{l}\text { Acquisition and } \\
\text { analysis of data }\end{array}$ \\
\hline $\begin{array}{l}\text { Ho Jin Kim, MD, } \\
\text { PhD }\end{array}$ & $\begin{array}{l}\text { National Cancer Center, } \\
\text { Goyang, Republic of Korea }\end{array}$ & $\begin{array}{l}\text { Acquisition and } \\
\text { analysis of data }\end{array}$ \\
\hline $\begin{array}{l}\text { Jae-Won Hyun, } \\
\text { MD, PhD }\end{array}$ & $\begin{array}{l}\text { University of Minas Gerais, } \\
\text { Medical School, Belo } \\
\text { Horizonte, Brazil }\end{array}$ & $\begin{array}{l}\text { Acquisition and } \\
\text { analysis of data }\end{array}$ \\
\hline $\begin{array}{l}\text { Jacqueline } \\
\text { Palace, MD }\end{array}$ & $\begin{array}{l}\text { Oxford University Hospitals, } \\
\text { National Health Service Trust, } \\
\text { Oxford, United Kingdom }\end{array}$ & $\begin{array}{l}\text { Acquisition and } \\
\text { analysis of data }\end{array}$ \\
\hline $\begin{array}{l}\text { Adriana Roca- } \\
\text { Fernandez, MSc }\end{array}$ & $\begin{array}{l}\text { Oxford University Hospitals, } \\
\text { National Health Service Trust, } \\
\text { Oxford, United Kingdom }\end{array}$ & $\begin{array}{l}\text { Acquisition and } \\
\text { analysis of data }\end{array}$ \\
\hline $\begin{array}{l}\text { Maria Isabel } \\
\text { Leite, MD, PhD }\end{array}$ & $\begin{array}{l}\text { Oxford University Hospitals, } \\
\text { National Health Service Trust, } \\
\text { Oxford, United Kingdom }\end{array}$ & $\begin{array}{l}\text { Acquisition and } \\
\text { analysis of data }\end{array}$ \\
\hline $\begin{array}{l}\text { Srilakshmi } \\
\text { Sharma, MD, PhD }\end{array}$ & $\begin{array}{l}\text { Oxford University Hospitals, } \\
\text { National Health Service Trust, } \\
\text { Oxford, United Kingdom }\end{array}$ & $\begin{array}{l}\text { Acquisition and } \\
\text { analysis of data }\end{array}$ \\
\hline $\begin{array}{l}\text { Fereshteh } \\
\text { Ashtari, MD }\end{array}$ & $\begin{array}{l}\text { Isfahan University of Medical } \\
\text { Sciences, Isfahan, Iran }\end{array}$ & $\begin{array}{l}\text { Acquisition and } \\
\text { analysis of data }\end{array}$ \\
\hline $\begin{array}{l}\text { Rahele Kafieh, } \\
\text { PhD }\end{array}$ & $\begin{array}{l}\text { Isfahan University of Medical } \\
\text { Sciences, Isfahan, Iran }\end{array}$ & $\begin{array}{l}\text { Acquisition and } \\
\text { analysis of data }\end{array}$ \\
\hline $\begin{array}{l}\text { Alireza Dehghani, } \\
\text { PhD }\end{array}$ & $\begin{array}{l}\text { Isfahan University of Medical } \\
\text { Sciences, Isfahan, Iran }\end{array}$ & $\begin{array}{l}\text { Acquisition and } \\
\text { analysis of data }\end{array}$ \\
\hline $\begin{array}{l}\text { Mohsen } \\
\text { Pourazizi, PhD }\end{array}$ & $\begin{array}{l}\text { Isfahan University of Medical } \\
\text { Sciences, Isfahan, Iran }\end{array}$ & $\begin{array}{l}\text { Acquisition and } \\
\text { analysis of data }\end{array}$ \\
\hline $\begin{array}{l}\text { Lekha Pandit, } \\
\text { MD, PhD }\end{array}$ & $\begin{array}{l}\text { KS Hegde Medical Academy, } \\
\text { Nitte University, Mangalore, } \\
\text { India }\end{array}$ & $\begin{array}{l}\text { Acquisition and } \\
\text { analysis of data }\end{array}$ \\
\hline $\begin{array}{l}\text { Anitha D'Cunha, } \\
\text { PhD }\end{array}$ & $\begin{array}{l}\text { KS Hegde Medical Academy, } \\
\text { Nitte University, Mangalore, } \\
\text { India }\end{array}$ & $\begin{array}{l}\text { Acquisition and } \\
\text { analysis of data }\end{array}$ \\
\hline Orhan Aktas, MD & $\begin{array}{l}\text { Heinrich Heine University } \\
\text { Düsseldorf, Düsseldorf, } \\
\text { Germany }\end{array}$ & $\begin{array}{l}\text { Acquisition and } \\
\text { analysis of data }\end{array}$ \\
\hline $\begin{array}{l}\text { Marius } \\
\text { Ringelstein, MD }\end{array}$ & $\begin{array}{l}\text { Heinrich Heine University } \\
\text { Düsseldorf, Düsseldorf, } \\
\text { Germany }\end{array}$ & $\begin{array}{l}\text { Acquisition and } \\
\text { analysis of data }\end{array}$ \\
\hline $\begin{array}{l}\text { Philipp Albrecht, } \\
\text { MD }\end{array}$ & $\begin{array}{l}\text { Heinrich Heine University } \\
\text { Düsseldorf, Düsseldorf, } \\
\text { Germany }\end{array}$ & $\begin{array}{l}\text { Acquisition and } \\
\text { analysis of data }\end{array}$ \\
\hline Eugene May, MD & $\begin{array}{l}\text { Swedish Neuroscience Institute } \\
\text { Neuro-Ophthalmology, Seattle, } \\
\text { WA }\end{array}$ & $\begin{array}{l}\text { Acquisition and } \\
\text { analysis of data }\end{array}$ \\
\hline Caryl Tongco & $\begin{array}{l}\text { Swedish Neuroscience Institute } \\
\text { Neuro-Ophthalmology, Seattle, } \\
\text { WA }\end{array}$ & $\begin{array}{l}\text { Acquisition and } \\
\text { analysis of data }\end{array}$ \\
\hline
\end{tabular}

Appendix (continued)

\begin{tabular}{lll}
\hline Name & Location & Contribution \\
\hline $\begin{array}{lll}\text { Letizia Leocani, } \\
\text { MD, PhD }\end{array}$ & $\begin{array}{l}\text { Institute of Experimental } \\
\text { Neurology, Scientific Institute } \\
\text { Hospital San Raffaele and } \\
\text { University Vita-Salute San } \\
\text { Raffaele, Milan, Italy }\end{array}$ & $\begin{array}{l}\text { Acquisition and } \\
\text { analysis of data }\end{array}$ \\
& $\begin{array}{l}\text { Institute of Experimental } \\
\text { Neurology, Scientific Institute } \\
\text { Marco Pisa, MD }\end{array}$ & $\begin{array}{l}\text { Acquisition and } \\
\text { analysis of data }\end{array}$ \\
& $\begin{array}{l}\text { University Vita-Salute San } \\
\text { Raffaele, Milan, Italy }\end{array}$ & \\
\hline
\end{tabular}

\begin{tabular}{lll}
\hline Marta Radaelli, & Institute of Experimental & Acquisition and \\
MD, PhD & Neurology, Scientific Institute & analysis of data \\
& Hospital San Raffaele and & \\
& University Vita-Salute San & \\
& Raffaele, Milan, Italy &
\end{tabular}

Elena H Martinez- Hospital Clinic of Barcelona- Acquisition and Lapiscina, MD, Institut d'Investigacions, analysis of data PhD Biomèdiques August Pi Sunyer, Barcelona, Spain

Hadas Stiebel- Sackler School of Medicine, Acquisition and

Kalish, MD Tel Aviv University, Tel Aviv, analysis of data Israel

Sasitorn Siritho, Siriraj Hospital and Acquisition and MD Bumrungrad International analysis of data Hospital, Bangkok, Thailand

\begin{tabular}{lll}
\hline $\begin{array}{l}\text { Jérome de Seze, } \\
\text { MD, PhD }\end{array}$ & $\begin{array}{l}\text { University Hospital of } \\
\text { Strasbourg, France }\end{array}$ & $\begin{array}{l}\text { Acquisition and } \\
\text { analysis of data }\end{array}$ \\
\hline $\begin{array}{l}\text { Thomas Senger, } \\
\text { MD }\end{array}$ & $\begin{array}{l}\text { University Hospital of } \\
\text { Strasbourg, France }\end{array}$ & $\begin{array}{l}\text { Acquisition and } \\
\text { analysis of data }\end{array}$ \\
\hline $\begin{array}{l}\text { Joachim Havla, } \\
\text { MD }\end{array}$ & $\begin{array}{l}\text { Ludwig-Maximilians } \\
\text { Universität Muenchen, } \\
\text { Munich, Germany }\end{array}$ & $\begin{array}{l}\text { Acquisition and } \\
\text { analysis of data }\end{array}$ \\
\hline $\begin{array}{l}\text { Romain } \\
\text { Marignier, MD, }\end{array}$ & $\begin{array}{l}\text { Pierre Wertheimer Neurological } \\
\text { Hospital, Hospices Civils de } \\
\text { Lyon, France }\end{array}$ & $\begin{array}{l}\text { Acquisition and } \\
\text { analysis of data }\end{array}$ \\
\hline $\begin{array}{l}\text { Alvaro Cobo } \\
\text { Calvo, MD, PhD }\end{array}$ & $\begin{array}{l}\text { Pierre Wertheimer } \\
\text { Neurological Hospital, } \\
\text { Hospices Civils de Lyon, } \\
\text { France; Hospital Universitari } \\
\text { Vall d'Hebron, Universitat } \\
\text { Autònoma de Barcelona, } \\
\text { Spain }\end{array}$ & $\begin{array}{l}\text { Acquisition and } \\
\text { analysis of data }\end{array}$ \\
\end{tabular}

Denis Bichuetti, Escola Paulista de Medicina, Acquisition and MD, PhD Universidade Federal de São analysis of data Paulo, São Paulo, Brazil

Ivan Maynart Escola Paulista de Medicina, Acquisition and Tavares, MD, PhD Universidade Federal de São analysis of data Paulo, São Paulo, Brazil

\begin{tabular}{lll}
\hline $\begin{array}{l}\text { Nasrin Asgari, } \\
\text { MD, PhD }\end{array}$ & $\begin{array}{l}\text { University of Southern } \\
\text { Denmark, Odense, } \\
\text { Denmark }\end{array}$ & $\begin{array}{l}\text { Acquisition and } \\
\text { analysis of data }\end{array}$ \\
\hline $\begin{array}{l}\text { Kerstin Soelberg, } \\
\text { MD }\end{array}$ & $\begin{array}{l}\text { University of Southern } \\
\text { Denmark, Odense, Denmark }\end{array}$ & $\begin{array}{l}\text { Acquisition and } \\
\text { analysis of data }\end{array}$ \\
\hline Ayse Altintas, MD & $\begin{array}{l}\text { Cerrahpasa Medical Faculty, } \\
\text { Istanbul University, } \\
\text { Cerrahpasa, Turkey }\end{array}$ & $\begin{array}{l}\text { Acquisition and } \\
\text { analysis of data }\end{array}$ \\
\hline $\begin{array}{l}\text { Rengin Yildirim, } \\
\text { MD }\end{array}$ & $\begin{array}{l}\text { Cerrahpasa Medical Faculty, } \\
\text { Istanbul University, } \\
\text { Cerrahpasa, Turkey }\end{array}$ & $\begin{array}{l}\text { Acquisition and } \\
\text { analysis of data }\end{array}$ \\
\hline
\end{tabular}


Appendix (continued)

\begin{tabular}{|c|c|c|}
\hline Name & Location & Contribution \\
\hline $\begin{array}{l}\text { Uygur Tanriverdi, } \\
\text { MD }\end{array}$ & $\begin{array}{l}\text { Cerrahpasa Medical Faculty, } \\
\text { Istanbul University, } \\
\text { Cerrahpasa, Turkey }\end{array}$ & $\begin{array}{l}\text { Acquisition and } \\
\text { analysis of data }\end{array}$ \\
\hline Anu Jacob, MD & $\begin{array}{l}\text { The Walton Centre for } \\
\text { Neurology and } \\
\text { Neurosurgery, Liverpool, } \\
\text { United Kingdom }\end{array}$ & $\begin{array}{l}\text { Acquisition and } \\
\text { analysis of data }\end{array}$ \\
\hline $\begin{array}{l}\text { Saif Huda, MD, } \\
\text { PhD }\end{array}$ & $\begin{array}{l}\text { The Walton Centre for } \\
\text { Neurology and } \\
\text { Neurosurgery, Liverpool, } \\
\text { United Kingdom }\end{array}$ & $\begin{array}{l}\text { Acquisition and } \\
\text { analysis of data }\end{array}$ \\
\hline Zoe Rimler, BSc & $\begin{array}{l}\text { NYU School of Medicine, New } \\
\text { York, NY }\end{array}$ & $\begin{array}{l}\text { Acquisition and } \\
\text { analysis of data }\end{array}$ \\
\hline Allyson Reid, MD & $\begin{array}{l}\text { NYU School of Medicine, New } \\
\text { York, NY }\end{array}$ & $\begin{array}{l}\text { Acquisition and } \\
\text { analysis of data }\end{array}$ \\
\hline $\begin{array}{l}\text { Yang Mao- } \\
\text { Draayer, MD, PhD }\end{array}$ & $\begin{array}{l}\text { University of Michigan } \\
\text { Medical School, Ann } \\
\text { Arbor, MI }\end{array}$ & $\begin{array}{l}\text { Acquisition and } \\
\text { analysis of data }\end{array}$ \\
\hline $\begin{array}{l}\text { Ibis Soto de } \\
\text { Castillo, MD }\end{array}$ & $\begin{array}{l}\text { Hospital Clínico de } \\
\text { Maracaibo, Maracaibo, } \\
\text { Venezuela }\end{array}$ & $\begin{array}{l}\text { Acquisition and } \\
\text { analysis of data }\end{array}$ \\
\hline $\begin{array}{l}\text { Axel Petzold, MD, } \\
\text { PhD }\end{array}$ & $\begin{array}{l}\text { University College London, } \\
\text { London, UK }\end{array}$ & $\begin{array}{l}\text { Conception and } \\
\text { design of the study }\end{array}$ \\
\hline Ari J Green, MD & $\begin{array}{l}\text { University of California San } \\
\text { Francisco, CA }\end{array}$ & $\begin{array}{l}\text { Conception and } \\
\text { design of the study }\end{array}$ \\
\hline $\begin{array}{l}\text { Michael R } \\
\text { Yeaman, MD, PhD }\end{array}$ & $\begin{array}{l}\text { University of California Los } \\
\text { Angeles, CA }\end{array}$ & $\begin{array}{l}\text { Conception and } \\
\text { design of the study }\end{array}$ \\
\hline Terry Smith, MD & $\begin{array}{l}\text { University of Michigan } \\
\text { Medical School, Ann } \\
\text { Arbor, MI }\end{array}$ & $\begin{array}{l}\text { Conception and } \\
\text { design of the study }\end{array}$ \\
\hline $\begin{array}{l}\text { Alexander U } \\
\text { Brandt, MD }\end{array}$ & $\begin{array}{l}\text { Experimental and Clinical } \\
\text { Research Center, Max } \\
\text { Delbrück Center for } \\
\text { Molecular Medicine and } \\
\text { Charité-Universitätsmedizin } \\
\text { Berlin, Berlin, Germany }\end{array}$ & $\begin{array}{l}\text { Acquisition and } \\
\text { analysis of data, } \\
\text { conception and design } \\
\text { of the study, and } \\
\text { drafting a significant } \\
\text { portion of the } \\
\text { manuscript or figures }\end{array}$ \\
\hline $\begin{array}{l}\text { Friedemann Paul, } \\
\text { MD }\end{array}$ & $\begin{array}{l}\text { Charité-Universitätsmedizin } \\
\text { Berlin, Corporate Member of } \\
\text { Freie Universität Berlin and } \\
\text { Humboldt-Universität zu } \\
\text { Berlin }\end{array}$ & $\begin{array}{l}\text { Acquisition and } \\
\text { analysis of data and } \\
\text { conception and design } \\
\text { of the study }\end{array}$ \\
\hline
\end{tabular}

\section{References}

1. Oertel FC, Zimmermann H, Paul F, Brandt AU. Optical coherence tomography in neuromyelitis optica spectrum disorders: potential advantages for individualized monitoring of progression and therapy. EPMA J. 2018;9(1): 21-33.

2. Schneider E, Zimmermann H, Oberwahrenbrock T, et al. Optical coherence tomography reveals distinct patterns of retinal damage in neuromyelitis optica and multiple sclerosis. PLoS One. 2013;8(6):e66151.

3. Bouyon $\mathrm{M}$, Collongues $\mathrm{N}$, Zéphir $\mathrm{H}$, et al. Longitudinal follow-up of vision in a neuromyelitis optica cohort. Mult Scler. 2013;19(10):1320-1322.

4. Sotirchos ES, Filippatou A, Fitzgerald KC, et al. Aquaporin-4 IgG seropositivity is associated with worse visual outcomes after optic neuritis than MOG-IgG seropositivity and multiple sclerosis, independent of macular ganglion cell layer thinning. Mult Scler. 2019;26(11):1360-1371.

5. Hamid SHM, Whittam D, Mutch K, et al. What proportion of AQP4-IgG-negative NMO spectrum disorder patients are MOG-IgG positive? A cross sectional study of 132 patients. J Neurol. 2017;264(10):2088-2094.

6. Oertel FC, Kuchling J, Zimmermann H, et al. Microstructural visual system changes in AQP4-antibody-seropositive NMOSD. Neurol Neuroimmunol Neuroinflamm. 2017; 4(3):e334.
7. Oertel FC, Havla J, Roca-Fernández A, et al. Retinal ganglion cell loss in neuromyelitis optica: a longitudinal study. J Neurol Neurosurg Psychiatry. 2018;89(12):1259-1265.

8. Huang D, Swanson EA, Lin CP, et al. Optical coherence tomography. Science. 1991, 254(5035):1178-1181.

9. Specovius S, Zimmermann HG, Oertel FC, et al. Cohort profile: a collaborative multicentre study of retinal optical coherence tomography in 539 patients with neuromyelitis optica spectrum disorders (CROCTINO). BMJ Open. 2020;10(10): e035397.

10. Motamedi S, Gawlik K, Ayadi N, et al. Normative data and minimally detectable change for inner retinal layer thicknesses using a semi-automated OCT image segmentation pipeline. Front Neurol. 2019;10:1117.

11. Wingerchuk DM, Banwell B, Bennett JL, et al. International consensus diagnostic criteria for neuromyelitis optica spectrum disorders. Neurology. 2015;85(2):177-189.

12. von Elm E, Altman DG, Egger M, et al. The strengthening the reporting of observational studies in epidemiology (STROBE) statement: guidelines for reporting observational studies. Int J Surg. 2014;12(12):1495-1499.

13. Tewarie $\mathrm{P}, \mathrm{Balk} \mathrm{L}$, Costello $\mathrm{F}$, et al. The OSCAR-IB consensus criteria for retinal OCT quality assessment. PLoS One. 2012;7(4):e34823.

14. Schippling S, Balk LJ, Costello F, et al. Quality control for retinal OCT in multiple sclerosis: validation of the OSCAR-IB criteria. Mult Scler. 2015;21(2):163-170.

15. Lang A, Carass A, Hauser M, et al. Retinal layer segmentation of macular OCT images using boundary classification. Biomed Opt Express. 2013;4(7):1133-1152.

16. R Development Core Team. R: A Language and Environment for Statistical Computing [online]. R Foundation for Statistical Computing; 2008. R-project.org.

17. Akaishi T, Kaneko K, Himori N, et al. Subclinical retinal atrophy in the unaffected fellow eyes of multiple sclerosis and neuromyelitis optica [online serial] J Neuroimmunol. 2017;313:10-15. Accessed October 8, 2017. jni-journal.com/article/ S0165-5728(17)30319-3/fulltext

18. Alshowaeir D, Yiannikas C, Fraser C, Klistorner A. Mechanism of delayed conduction of fellow eyes in patients with optic neuritis. Int J Ophthalmol. 2018;11(2): 329-332.

19. Manogaran P, Traboulsee AL, Lange AP. Longitudinal study of retinal nerve fiber layer thickness and macular volume in patients with neuromyelitis optica spectrum disorder. J Neuroophthalmol. 2016;36(4):363-368.

20. Kaufhold F, Zimmermann H, Schneider E, et al. Optic neuritis is associated with inner nuclear layer thickening and microcystic macular edema independently of multiple sclerosis. PLoS One. 2013;8(8):e71145.

21. Knier B, Schmidt P, Aly L, et al. Retinal inner nuclear layer volume reflects response to immunotherapy in multiple sclerosis. Brain. 2016;139(11):2855-2863.

22. Petzold A, Balcer LJ, Calabresi PA, et al. Retinal layer segmentation in multiple sclerosis: a systematic review and meta-analysis. Lancet Neurol. 2017;16(10):797-812.

23. Pawlitzki M, Horbrügger M, Loewe $\mathrm{K}$, et al. MS optic neuritis-induced long-term structural changes within the visual pathway. Neurol Neuroimmunol Neuroinflamm. 2020;7(2):e665.

24. Pache F, Zimmermann H, Mikolajczak J, et al. MOG-IgG in NMO and related disorders: a multicenter study of 50 patients. Part 4: afferent visual system damage after optic neuritis in MOG-IgG-seropositive versus AQP4-IgG-seropositive patients. J Neuroinflammation. 2016;13(1):282.

25. Filippatou AG, Vasileiou ES, He Y, et al. Evidence of subclinical quantitative retinal layer abnormalities in AQP4-IgG seropositive NMOSD. Mult Scler. 2020 Dec 14, 1352458520977771. doi: 10.1177/1352458520977771.

26. Motamedi S, Oertel FC, Yadav SK, et al. Altered fovea in AQP4-IgG-seropositive neuromyelitis optica spectrum disorders. Neurol Neuroimmunol Neuroinflamm. 2020; 7(5):e805.

27. Roca-Fernández A, Oertel FC, Yeo T, et al. Foveal changes in AQP4-Ab seropositive NMOSD are independent of optic neuritis and not overtly progressive. Eur J Neurol. 2021;28(7):2280-2293.

28. Papadopoulou A, Oertel FC, Chien C, et al. Lateral geniculate nucleus volume changes after optic neuritis in neuromyelitis optica: a longitudinal study. Neuroimage Clin. 2021;30:102608.

29. Ringelstein M, Harmel J, Zimmermann H, et al. Longitudinal optic neuritis-unrelated visual evoked potential changes in NMO spectrum disorders. Neurology. 2020;94(4): e407-e418.

30. Pache F, Zimmermann H, Finke C, et al. Brain parenchymal damage in neuromyelitis optica spectrum disorder-a multimodal MRI study. Eur Radiol. 2016;26(12) 4413-4422.

31. Hokari M, Yokoseki A, Arakawa M, et al. Clinicopathological features in anterior visual pathway in neuromyelitis optica. Ann Neurol. 2016;79(4):605-624.

32. You Y, Zhu L, Zhang T, et al. Evidence of müller glial dysfunction in patients with aquaporin-4 immunoglobulin G-positive neuromyelitis optica spectrum disorder. Ophthalmology. 2019;126(6):801-810. Elsevier.

33. Chien C, Scheel M, Schmitz-Hübsch T, et al. Spinal cord lesions and atrophy in NMOSD with AQP4-IgG and MOG-IgG associated autoimmunity. Mult Scler. 2019; 25(14):1926-1936

34. Felix CM, Levin MH, Verkman AS. Complement-independent retinal pathology produced by intravitreal injection of neuromyelitis optica immunoglobulin G. J Neuroinflammation. 2016;13(1):275.

35. Balk LJ, Coric D, Knier B, et al. Retinal inner nuclear layer volume reflects inflammatory disease activity in multiple sclerosis; a longitudinal OCT study. Mult Scler J Exp Transl Clin. 2019;5(3):2055217319871582.

36. Gelfand JM, Nolan R, Schwartz DM, Graves J, Green AJ. Microcystic macular oedema in multiple sclerosis is associated with disease severity. Brain. 2012;135(pt 6) 1786-1793. 
37. Gelfand JM, Cree BA, Nolan R, Arnow S, Green AJ. Microcystic inner nuclear layer abnormalities and neuromyelitis optica. JAMA Neurol. 2013;70(5):629-633.

38. Oberwahrenbrock T, Weinhold M, Mikolajczak J, et al. Reliability of intra-retinal layer thickness estimates. PLoS One. 2015;10(9):e0137316.

39. Borisow N, Kleiter I, Gahlen A, et al. Influence of female sex and fertile age on neuromyelitis optica spectrum disorders. Mult Scler. 2017;23(8):1092-1103.
40. Mori M, Kuwabara S, Paul F. Worldwide prevalence of neuromyelitis optica spectrum disorders. J Neurol Neurosurg Psychiatry. 2018;89(6):555-556.

41. Oertel FC, Paul F. Accelerating clinical research in neuromyelitis optica spectrum disorders [online serial]. Clin Exp Neuroimmunol. 2021;12(2):89-91. Accessed March 28, 2021. pericles.pericles-prod.literatumonline.com/doi/abs/10.1111/ cen3.12637. 


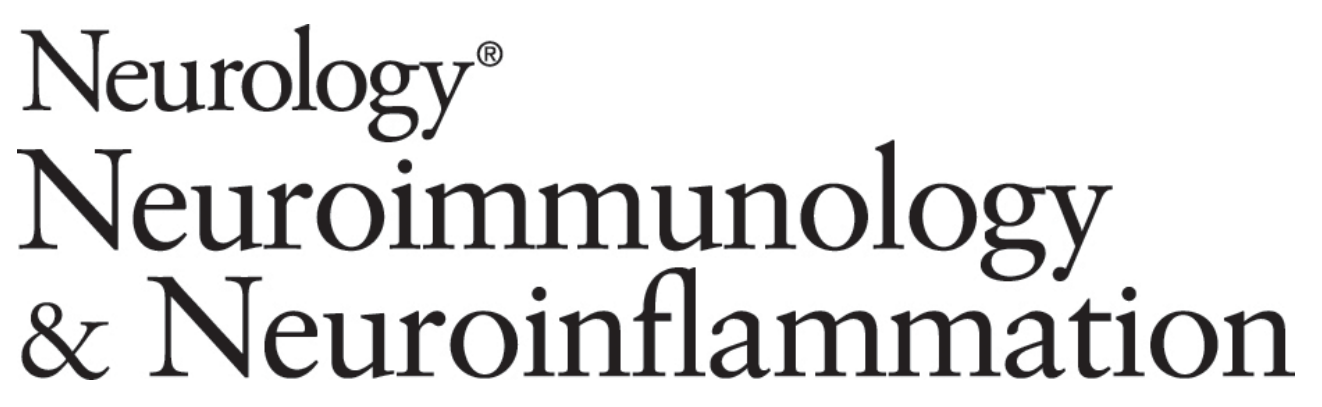

Retinal Optical Coherence Tomography in Neuromyelitis Optica Frederike Cosima Oertel, Svenja Specovius, Hanna G. Zimmermann, et al. Neurol Neuroimmunol Neuroinflamm 2021;8;

DOI 10.1212/NXI.0000000000001068

This information is current as of September 15, 2021

Neurol Neuroimmunol Neuroinflamm is an official journal of the American Academy of Neurology. Published since April 2014, it is an open-access, online-only, continuous publication journal. Copyright Copyright $\odot 2021$ The Author(s). Published by Wolters Kluwer Health, Inc. on behalf of the American Academy of Neurology.. All rights reserved. Online ISSN: 2332-7812.

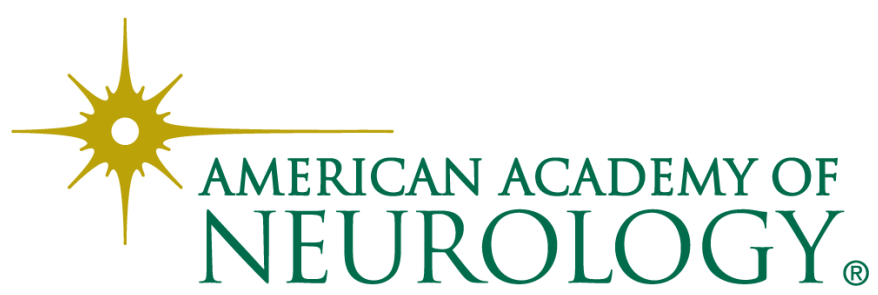




\section{Updated Information \& Services}

References

Citations

Subspecialty Collections

Errata

Permissions \& Licensing

\section{Reprints}

including high resolution figures, can be found at: http://nn.neurology.org/content/8/6/e1068.full.html

This article cites 40 articles, 7 of which you can access for free at: http://nn.neurology.org/content/8/6/e1068.full.html\#\#ref-list-1

This article has been cited by 3 HighWire-hosted articles: http://nn.neurology.org/content/8/6/e1068.full.html\#\#otherarticles

This article, along with others on similar topics, appears in the following collection(s):

All Imaging

http://nn.neurology.org//cgi/collection/all_imaging

Devic's syndrome

http://nn.neurology.org//cgi/collection/devics_syndrome

Optic neuritis; see Neuro-ophthalmology/Optic Nerve

http://nn.neurology.org//cgi/collection/optic_neuritis

\section{Retina}

http://nn.neurology.org//cgi/collection/retina

Visual loss

http://nn.neurology.org//cgi/collection/visual_loss

An erratum has been published regarding this article. Please see next page or:

/content/9/2/e1132.full.pdf

Information about reproducing this article in parts (figures,tables) or in its entirety can be found online at:

http://nn.neurology.org/misc/about.xhtml\#permissions

Information about ordering reprints can be found online: http://nn.neurology.org/misc/addir.xhtml\#reprintsus

Neurol Neuroimmunol Neuroinflamm is an official journal of the American Academy of Neurology.

Published since April 2014, it is an open-access, online-only, continuous publication journal. Copyright

Copyright $\odot 2021$ The Author(s). Published by Wolters Kluwer Health, Inc. on behalf of the American Academy of Neurology.. All rights reserved. Online ISSN: 2332-7812.

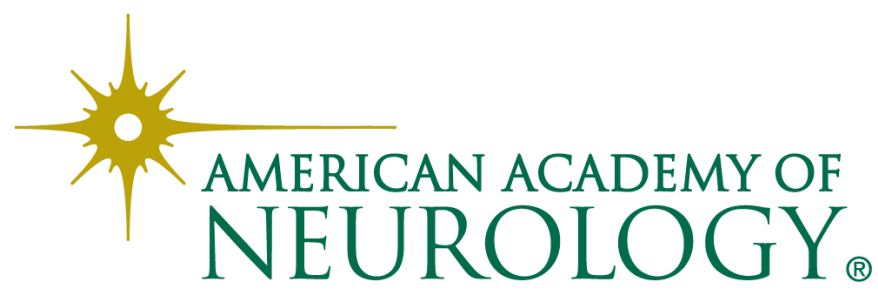




\section{Retinal Optical Coherence Tomography in Neuromyelitis Optica}

Neurol Neuroimmunol Neuroinflamm 2022;9:e1132. doi:10.1212/NXI.0000000000001132

In the Article "Retinal Optical Coherence Tomography in Neuromyelitis Optica" by Oertel et al. ${ }^{1}$, the 37 th author should be listed as "Alvaro Cobo-Calvo." The authors regret the error.

\section{Reference}

1. Oertel FC, Specovius S, Zimmermann HG, et al. Retinal optical coherence tomography in neuromyelitis optica. Neurol Neuroimmunol Neuroinflamm. 2021;8(6):e1068. 